\title{
Early medieval settlement and ironworking in Dornoch, Sutherland: excavations at The Meadows Business Park
}

by Russel Coleman and Effie Photos-Jones

with contributions by

Simon Chenery, Adrian Cox, Derek Hall, Mhairi Hastie and Catherine Smith

Scottish Archaeological Internet Report 28, 2008 www.sair.org.uk 
Published by the Society of Antiquaries of Scotland, www.socantscot.org.uk with Historic Scotland, www.historic-scotland.gov.uk and the Council for British Archaeology, www.britarch.ac.uk

Editor Helen Bleck

Produced by Archetype Information Technology Ltd, www.archetype-it.com

ISBN: 9780903903974

ISSN: $1773-3803$

Requests for permission to reproduce material from a $S A I R$ report should be sent to the Director of the Society of Antiquaries of Scotland, as well as to the author, illustrator, photographer or other copyright holder.

Copyright in any of the Scottish Archaeological Internet Reports series rests with the SAIR Consortium and the individual authors.

The consent does not extend to copying for general distribution, advertising or promotional purposes, the creation of new collective works or resale. 


\section{Contents}

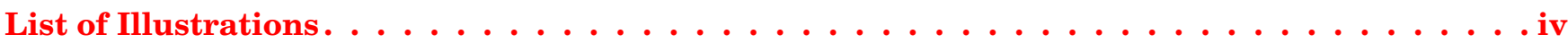

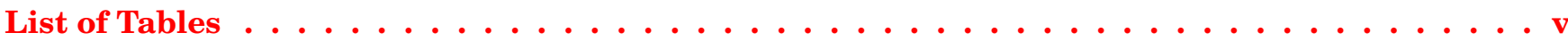

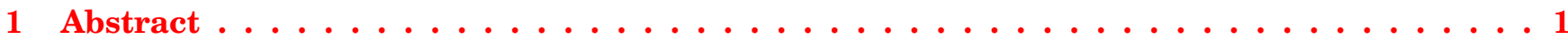

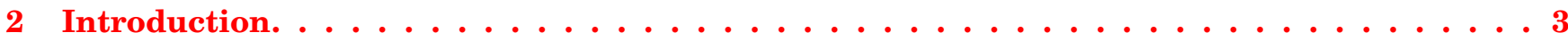

2.1 Historical and archaeological background $\ldots \ldots \ldots \ldots \ldots \ldots \ldots$

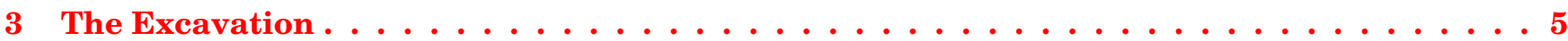

3.1 Phase 1: ditches and iron-making and -working (8th-9th centuries AD) (illus 4a) $\ldots \ldots \ldots$

3.1 .1 Ditches . . . . . . . . . . . . . . . . . . . . . . .5

3.1.2 Iron-making / working debris, hearth and pits . . . . . . . . . . . . . .5

3.2 Phase 2: building, enclosures, pits and ironworking (9th-10th centuries AD) (illus 4b) . . . . . .5

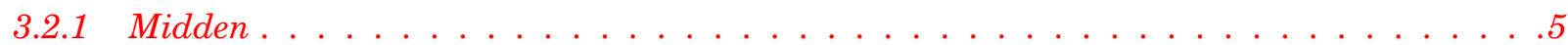

3.2.2 Large enclosure. . . . . . . . . . . . . . . . . . . . . . . . . . . . . .7

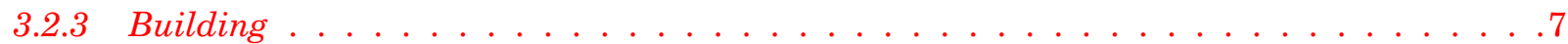

3.2.4 Small enclosure and gullies . . . . . . . . . . . . . . . . . . . .

3.3 Phase 3 : enclosure $(10$ th-11th centuries ad) (illus $4 c) \ldots \ldots \ldots \ldots$

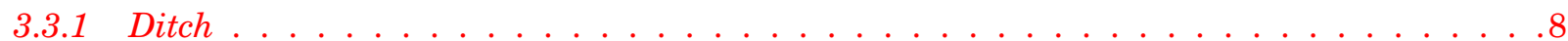

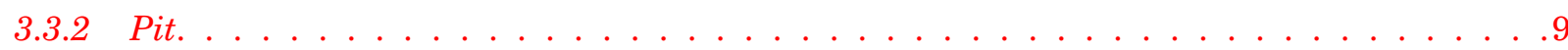

3.4 Phase 4 : medieval features $(15$ th century ad) (illus $4 \mathrm{~d}) \ldots \ldots \ldots \ldots \ldots$

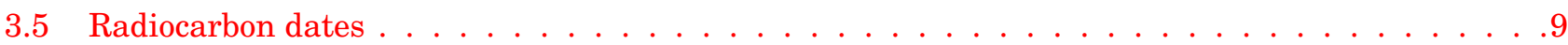

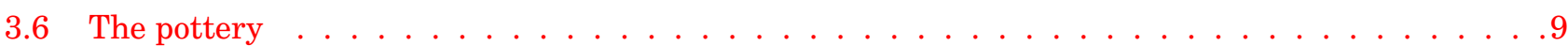

3.6.1 Geochemical fingerprinting of Dornoch pottery . . . . . . . . . . . . . . . . 10

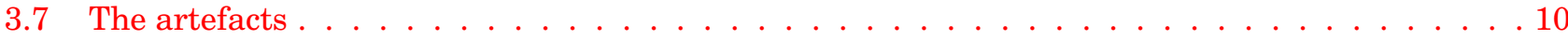

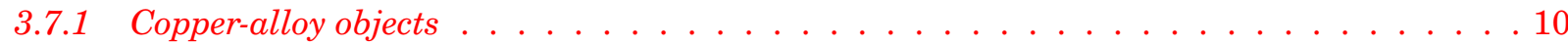

3.7 .2 Bone objects . . . . . . . . . . . . . . . . . . . . 12

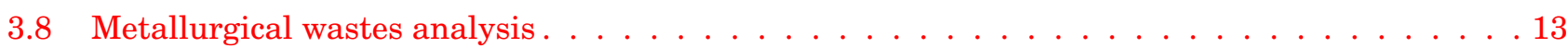

3.8.1 Introduction: setting the scene. . . . . . . . . . . . . . . . . . . . . . 13

3.8 .2 The site . . . . . . . . . . . . . . . . . . . . . . . . 14

3.8 .3 About bloomery iron-making . . . . . . . . . . . . . . . . . . . 14

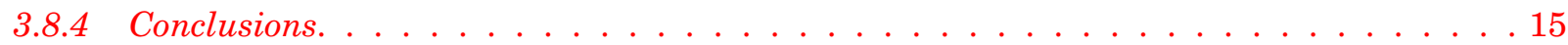

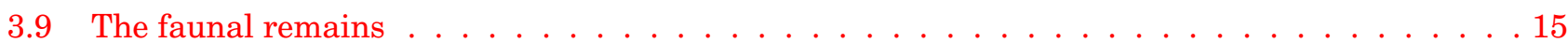

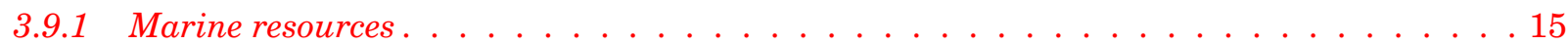

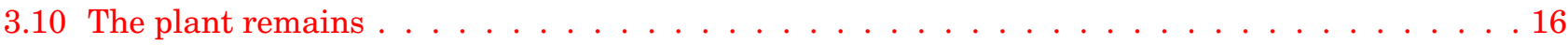

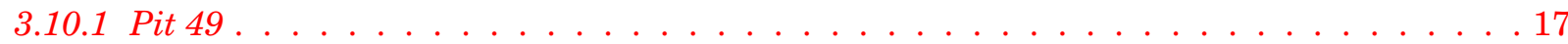

3.10 .2 Significance of the cereal remains . . . . . . . . . . . . . . . . . . . . 17

3.10 .3 Wood Charcoal Identifications. . . . . . . . . . . . . . . . . . . . . . . . . . 17

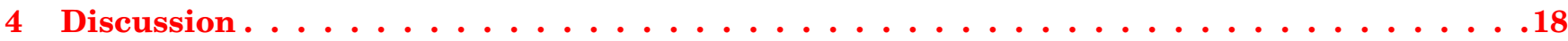

5 Acknowledgements. ............................20

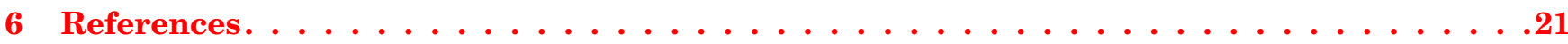




\section{List of Illustrations}

(All copyright: the authors, unless otherwise stated)

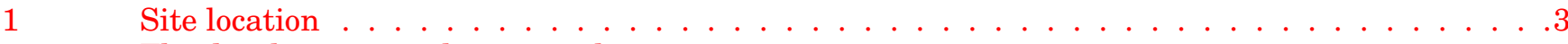

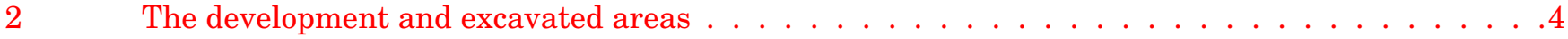

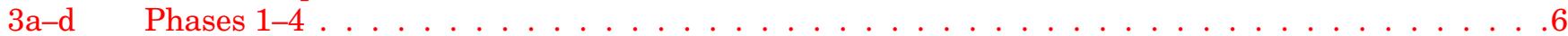

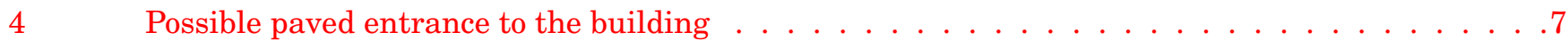

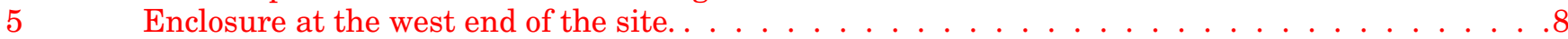

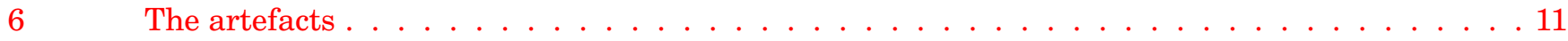

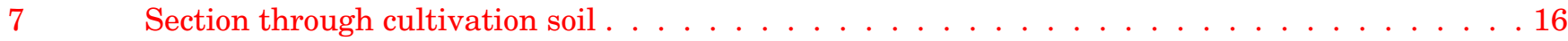

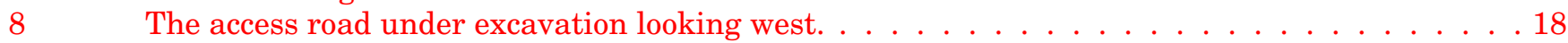




\section{List of Tables}

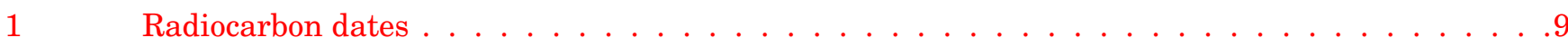

$2 \quad$ Features with dimensions and descriptions of fills . . . . . . . . . . . . . . . . . 13 


\section{Abstract}

Monitoring and excavation during the development of a new business park in Dornoch in 1997 revealed numerous features including a building, ditched enclosures and several hearths, all sealed beneath an artefact-rich cultivation soil. Radiocarbon dates obtained place the main period of activity here in the late 1st millennium AD. The evidence recovered also suggests a tradition of ironworking here from the early medieval period continuing through into the medieval period. A small assemblage of finds was recovered from the excavation, including quantities of iron slag, bog iron ore, fragments from a clay-lined furnace, whale bone, a bone counter and a bone pin beater. This paper reports on the results of the work and includes an extended section on the analysis of the iron-making and -working evidence.

The post-excavation analysis and reporting of the results was funded by Historic Scotland. 


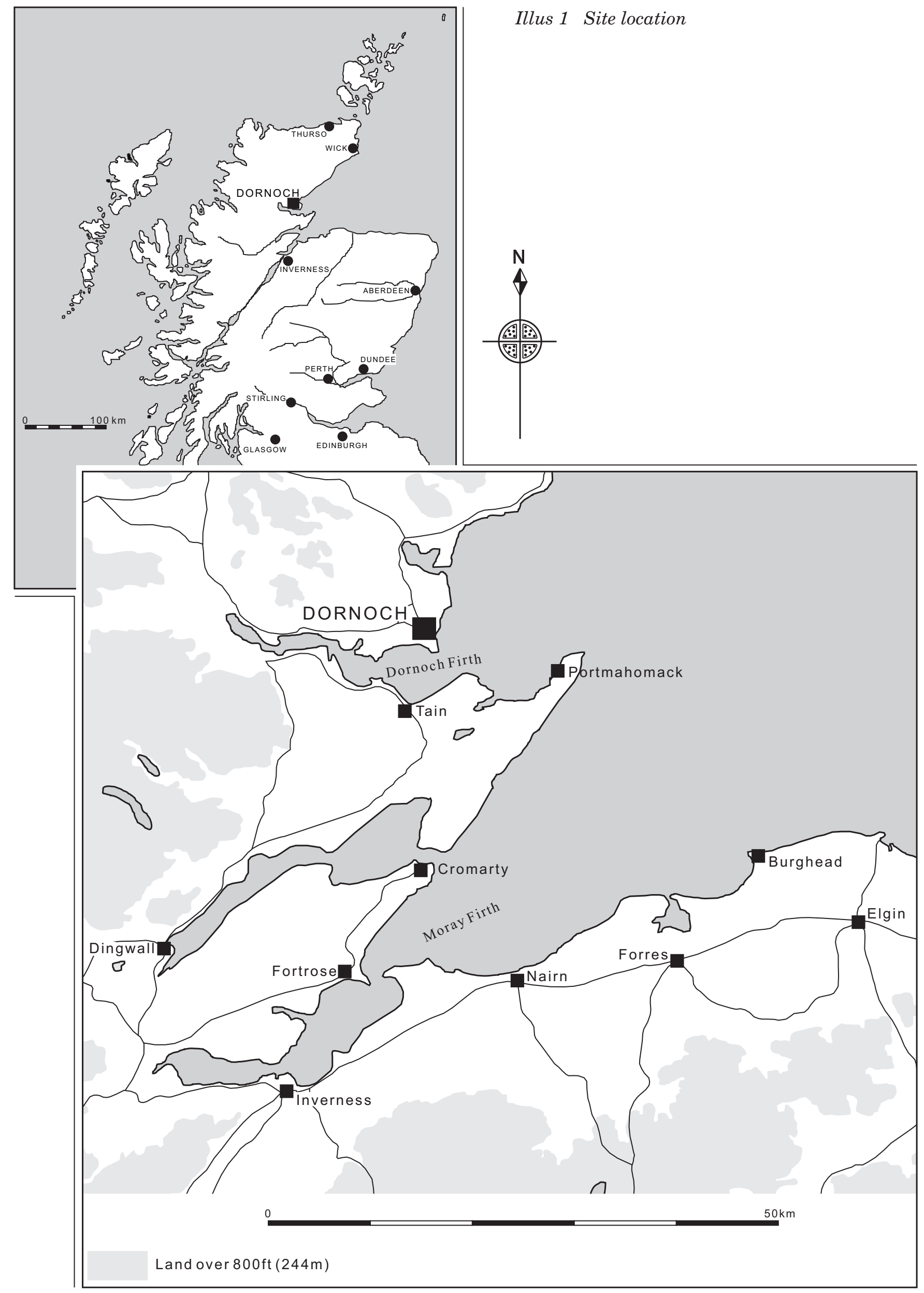




\section{Introduction}

A watching brief was carried out initially by Charlie Miller of Resurgam! and then jointly with SUAT Ltd in May 1997 on the development site of a new business park in Dornoch (illus 1). The site lay immediately to the south of the former Bishop's Palace (part of which is now the Dornoch Castle Hotel) on the southern edge of the burgh (illus 2) and just outside the area of archaeological interest as defined in Historic Dornoch: The Archaeological Implications of Development (Simpson \& Stevenson 1982). To the south of the site, the low-lying fields and machair stretch uninterrupted to the Dornoch Firth. The burgh of Tain lies just across the Dornoch Firth to the south, and the important site recently excavated at Portmahomack further along the Dornoch Firth to the south-east.

The watching brief involved monitoring the final phase of ground works, in particular the topsoil stripping of a new access road (illus 2). This revealed numerous features including a building, ditched enclosures and evidence for ironworking, all sealed beneath an artefact-rich cultivation soil (illus 7). In consultation with Highland Council, the developer, and Highland Council Archaeology Services as curator, salvage excavation was agreed. Over the May Bank Holiday weekend the Tain Archaeology Group and students from the Aberdeen University Certificate of Field Archaeology course kindly helped out.

\subsection{Historical and archaeological background}

The Dornoch Firth was a crucial place in the emergence of the Scottish nation in the early Middle Ages. The Norse and Celts in northern Scotland, led by their respective political rulers the earls of Orkney and the Mormaers, struggled to control Easter Ross, which lay between the earldom of Caithness (which included Sutherland) and the mormaerdom of Moray (Crawford 1995a, 2).

The Dornoch Firth seems to have been the boundary between the two cultural groups and has been the subject of much discussion (Crawford 1986, 1987, 1995a, 1995b). Though later (13th-century) Icelandic saga writers refer to the Ekkialsbakki (thought to be the River Oykell, which flows into the Dornoch Firth) as the extent of the conquests of some of the early earls of Orkney (Sigurd the Mighty and Thorstein the Red), there was no geographical reason why the Norse should have contented themselves with the Dornoch Firth as the southern limit of their expansion (Crawford 1986, 33-5). The attraction of good land led the Norse to attempt to control land further south both politically and territorially. The earls of Orkney and Caithness also attempted to rule in the Hebrides, and control of the firthlands ensured free access to the Great Glen and a through route to the southwest, thus avoiding a long and difficult sea voyage. South of the Dornoch Firth also offered access to rich resources of timber in Easter Ross, which they must surely have exploited for the maintenance of their existing fleet and the building of new vessels (Crawford 1995a, 11-17).

Very little is known about the origins and development of early medieval Dornoch, and precisely what prompted the establishment of the cathedral in the 13th century, but there must have been some pre-13th-century importance attached to the site to encourage such a development (Simpson \& Stevenson 1982,10). The first direct reference to settlement in Dornoch is, however, not until the early 12 th century. Contained in a writ by David I (1127 x 1153), recorded in the Dunfermline Abbey register, it orders Rognvald, Earl of Orkney, to respect the monks at Dornoch and has led to the suggestion that monks from Dunfermline had established a cell in Dornoch (Cowan \& Easson 1976, 203-204). Dornoch is traditionally associated with St Barr or St Finbarr (died AD 610), a disciple of St Ninian of Whithorn, and it is possible that a community of Celi De monks had established a cell there (Cowan \& Easson 1976, 52, 61). It has been claimed that the remains of this early monastery were found during excavations for the public school in the mid 19th century (Scott 1915, 24).

The see was probably founded by David I $c 1147 \mathrm{x}$ 1151 as part of a deliberate policy of detaching this remote and partly Norse-speaking province, which had been under the political influence of the earls of Orkney, and may have been ecclesiastically under the Bishops of Orkney, from Norse loyalties (Barrow 1981, 68). It was not until the 13th century, in fact, that the see was moved from Norse-dominated Halkirk to the more southerly church of Dornoch in the Gaelicspeaking part of the diocese. Other than the cathedral and Bishop's Palace (illus 2), little is known of medieval settlement here. Despite its early history, the town itself was not officially recognised as a burgh until it received its charter from Charles I in 1628.

The development area lies on the southern edge of the burgh and has been under pasture since at least the First Edition OS map of the town, when it was known as The Glebe. 


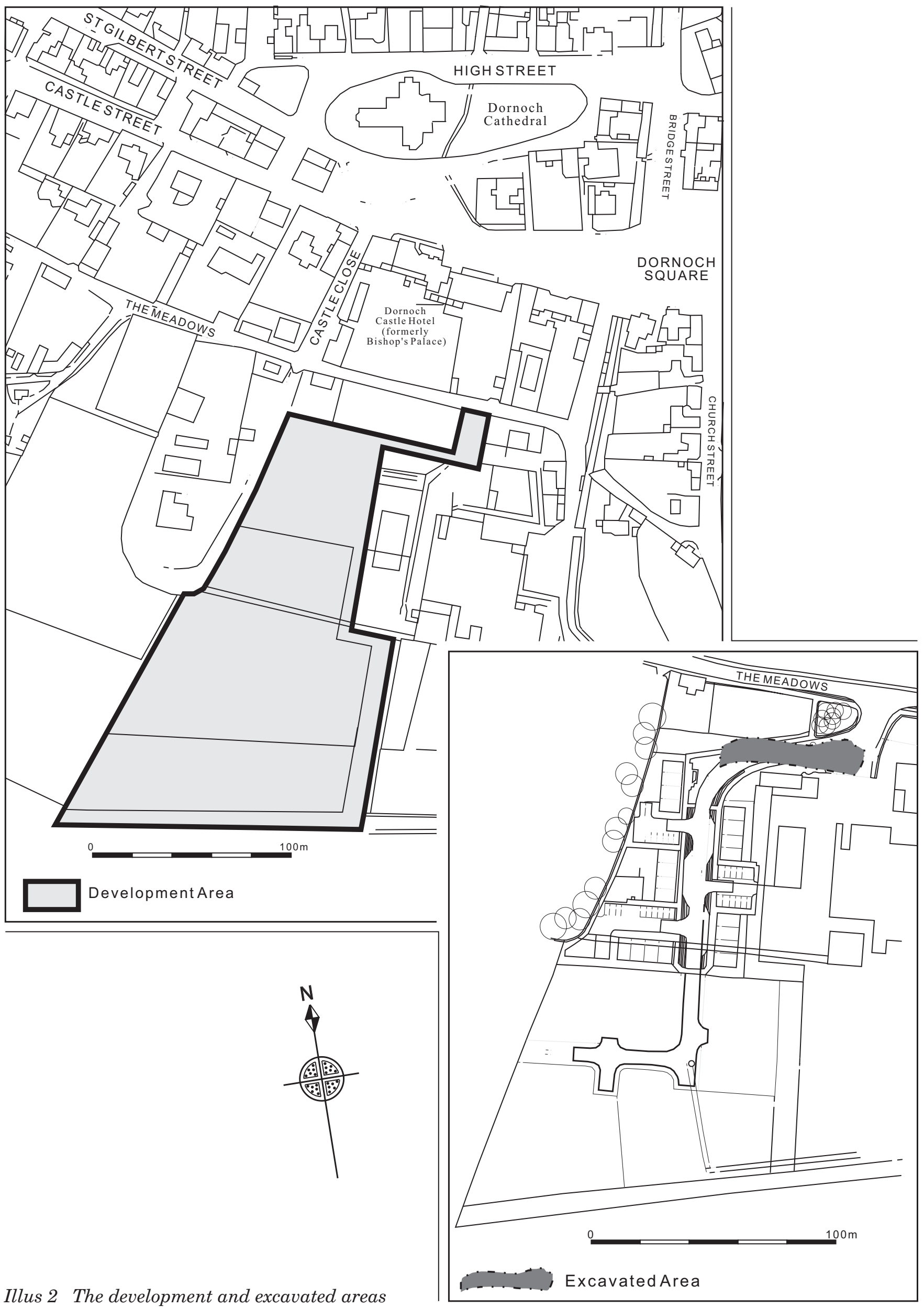




\section{The excavation}

Topsoil was stripped off by machine down to the natural sand sub-soil and dumped on the adjacent field to the south of the site by a fleet of tipper trucks. As the main part of the site, where the business units were to be sited, had already been stripped before formal archaeological intervention was arranged, the watching brief and subsequent excavation focused on the new access road at the north end of the site, an area measuring approximately $70 \mathrm{~m}$ by $15 \mathrm{~m}$ (illus 2 ).

The topsoil stripping revealed a scatter of largely isolated ditches and other cut features at the west end of the site, in contrast to a denser concentration of intercutting ditches and pits at the east end of the site, all of which could only be rapidly excavated and recorded. The radiocarbon dates obtained in association with the better understood stratigraphic relationships have allowed a basic sequence to be established. The earliest phase of activity seems to date to the 8th-9th centuries $\mathrm{AD}$, with the second and main phase of activity in the 10th century possibly extending into the 11th century; there was one isolated feature dating to the 15 th century.

\subsection{Phase 1: ditches and iron-making/ working (8th-9th centuries AD) (illus 3a)}

The earliest phase of activity on the site comprised two intercutting ditches, a gully and several small pits at the east end of the site, and at the western end of the site, a slag-rich soil containing large quantities of iron slag, fragments of clay furnace and a possible hearth.

\subsubsection{Ditches}

The earliest features comprised two intercutting ditches at the eastern end of the site on an E-W alignment. One fragment of slag was recovered from the fill. These ditches were truncated by the earliest datable feature identified in the excavations, a narrow, $\mathrm{N}-\mathrm{S}$-aligned gully. This had been filled with charcoal, cockle and whelk shells and charred barley grain in addition to a whale vertebra, fish bone (cod family), a sheep bone and a pig bone. The charred barley grain provided a radiocarbon date (OxA-9353) in the 8th, possibly 9th century AD (see Radiocarbon dates below). The lower fill contained pieces of a clay furnace or hearth, large lumps of slag and a fragment of iron.

\subsubsection{Iron-making/working debris, hearth and pits}

There were several small pits at the eastern end of the site. These included a shallow pit cutting through one of the intercutting ditches at the southeastern edge of the site. This contained burnt and unburnt bone, charcoal, flecks of burnt clay, sheep/ goat bone, shell, charred matter and heather twigs. To the west was a possible post-pit which contained large packing stones.

At the western end of the site was further evidence of ironworking. An area of disturbed natural sand subsoil filling a hollow in the underlying natural was found to contain large quantities of smelting slag and fragments of partly vitrified hearth or furnace remains. A fragment of a tuyere, a nozzle through which air is blown into a furnace, was also recovered from this layer.

Cutting through this slag-rich soil were several undated features which may have been associated with ironworking. These include a possible hearth, containing successive layers of burnt sand with shell and charcoal fragments, and a pit with four depressions in the base of the cut, which may have supported a structure of some sort.

Immediately to the east of the hearth was what appeared to be the remains of a turf bank, comprising reddish orange sand, with mussel shell, bone, charcoal and one flax seed present. The bank was up to $1.8 \mathrm{~m}$ wide in places and ran $\mathrm{N}-\mathrm{S}$ across the site.

\subsection{Phase 2: building, enclosures, pits and ironworking (9th-10th centuries AD) (illus 3b)}

In Phase 2, an enclosure was established in the eastern half of the site within which a building was erected. Quantities of iron slag, fired clay and bog iron recovered from numerous features associated with this phase indicate that iron-making and -working continued to be a core activity.

\subsubsection{Midden}

Dumped against the turf bank was a spread of midden containing a large lump of quality bog iron ore, charcoal, pieces of slag and burnt bone. Fragments of cattle and sheep/goat bone were also recovered, together with cockle and snail shell, charred barley and oat grains. Charred barley grain provided a radiocarbon date (OxA-9351) in the 10th, possibly 9 th century AD. 

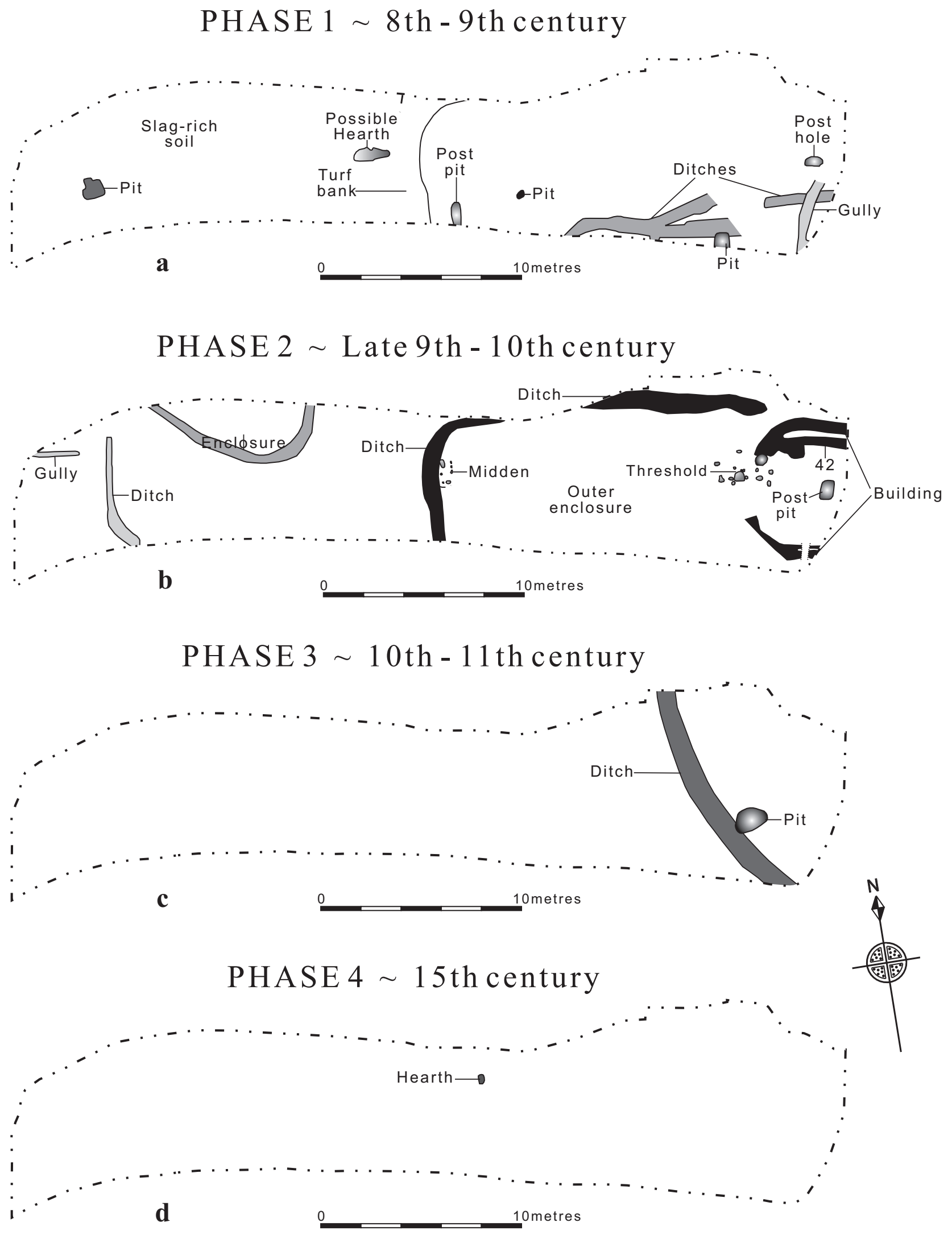

Illus 3a-d Phases 1-4 


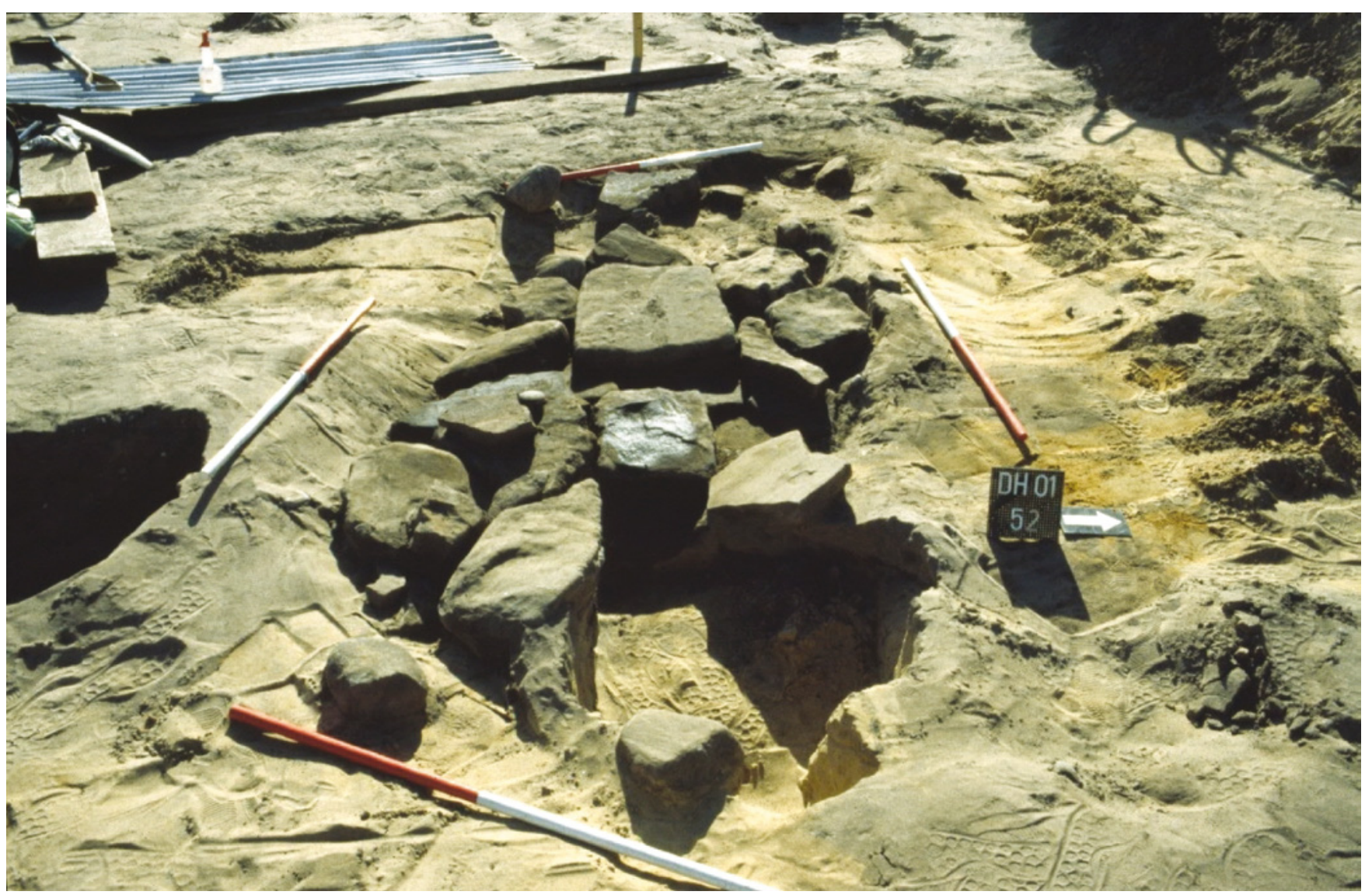

Illus 4 Possible paved entrance to the building

\subsubsection{Large enclosure}

Cutting through the midden was a ditch which formed the western end of a large, possibly subrectangular, enclosure. The western and northern sides of the enclosure ditch were traced in plan but the remainder lay beyond the main south section. The ditch itself was flat-bottomed and measured $0.65 \mathrm{~m}$ across and $0.2 \mathrm{~m}$ deep. It contained a single fill with occasional inclusions of animal and fish bone, cockle and mussel shell, charcoal, charred oat and hulled barley.

\subsubsection{Building}

At the eastern end of the enclosure, partially exposed and continuing beyond the excavation area, was a building (illus 8). Although disturbed by later features, the structure was represented by a pair of closely spaced, parallel ditches on the north side with a single ditch on the south side only just visible (any second ditch would have lain beyond the south section). The outer of the two ditches may have functioned as a drip trench. Some charcoal fragments and a small piece of slag were found in the fill.

As the building is incomplete, it is not clear whether it was a small sub-rectangular building with rounded corners, or whether the visible remains represent one end of a longer rectangular building with rounded ends. Internally the building would have measured $c 5 \mathrm{~m}$ from N-S and at least $4 \mathrm{~m} \mathrm{E-W}$. Both ditches had vertical sides and flat bases and were $c 0.4 \mathrm{~m}$ deep, and $c 0.5 \mathrm{~m}$ wide. The fill of the inner ditch contained a large lump of slag or iron and one smaller fragment of slag. The fill of the outer ditch was more organic in content. A curved strip of iron was recovered from the fill.

There was a gap through these ditches on the west side surfaced with a series of flat stones (illus 4). The largest slab lay at the centre, with smaller stones and pebbles packed around it. Cockles, mussels, charcoal, small pieces of slag and charred barley grain were also found in the packing between the stones, but may represent trample over the threshold. Charred barley grain from the trample material provided a radiocarbon date (OxA-9352) in the 10th century, or possibly earlier, in the 9 th century AD.

A post-pit, sub-rectangular in plan and which lay roughly central within the building, may have been a roof support. The post-pit could represent the single central post of a smaller structure, or one of a central line of posts. It was packed full of charcoal, numerous fragments of clay furnace or hearth lining, numerous small fragments of 


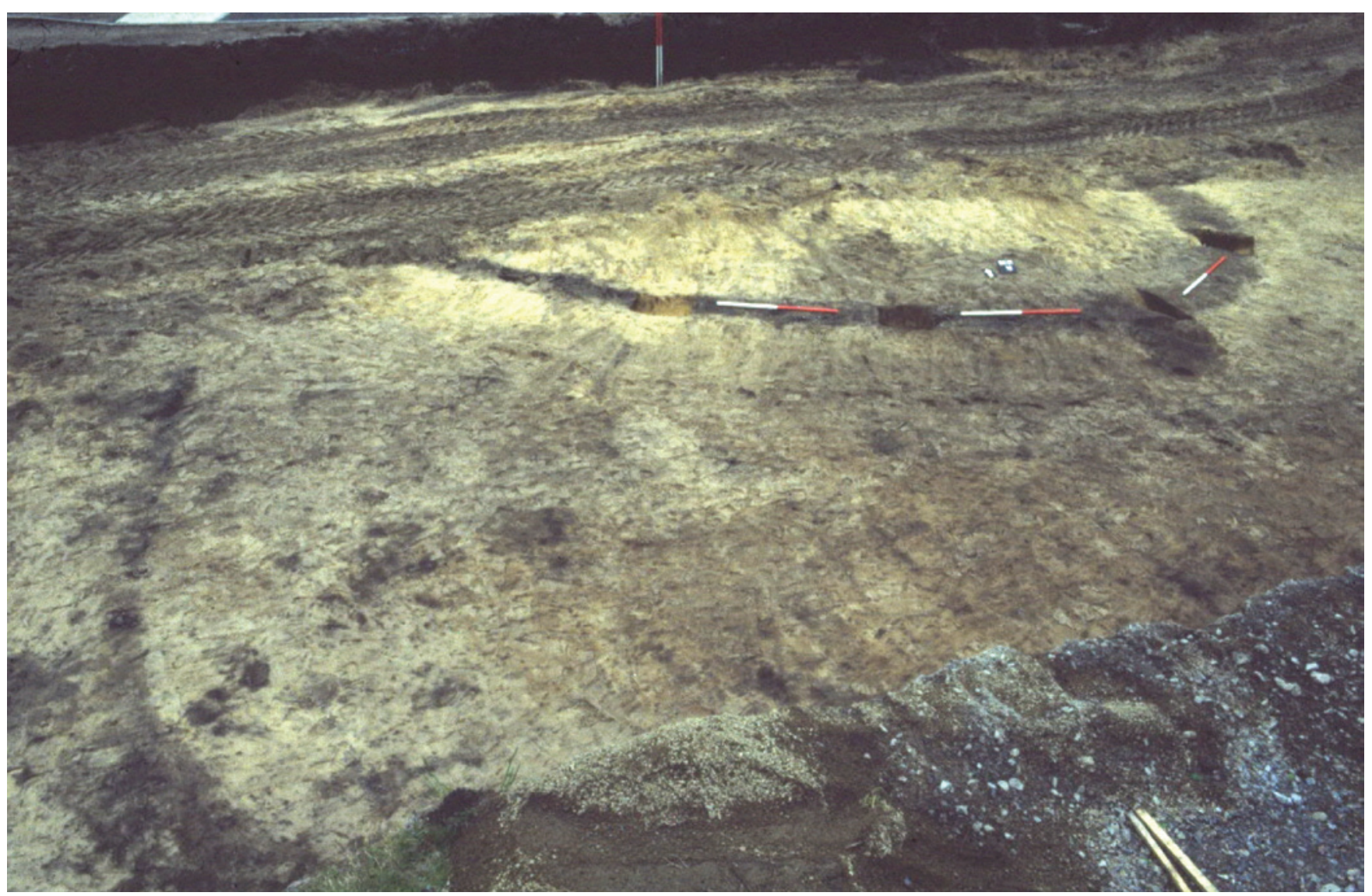

Illus 5 Enclosure at the west end of the site. The discoloured 'natural' sand was packed full of slag and fragments of clay furnace lining

slag and hammer-scale, a fire-cracked stone, small fragments of shell and barley grains and two iron objects, possibly nails, all in a blackened sand matrix. The charred barley grain produced a radiocarbon date in the 10 th-11th century $\mathrm{AD}$ (OxA-9513). The pit seems to have been backfilled, presumably after the building itself went out of use (see Phase 3).

\subsubsection{Small enclosure and gullies}

At the western end of the site, and cut into the slag-rich soil, were three linear features (illus 5). The most substantial of these was a curvilinear ditch $0.35 \mathrm{~m}$ wide and $0.2 \mathrm{~m}$ deep. Thought to be an enclosure, it was only partially exposed in the floor of the trench, the remainder extending beyond the north section. The upper fill contained frequent shell inclusions, fragments of sheep/ goat bone, one fragment of a young calf bone and frequent small pieces of slag. In parts, the fill was almost pure shell. Occasional charred grains of barley were present, a sample of which provided a radiocarbon date (OxA-9349) in the 10th, possibly 9 th, century AD.

To the south-west lay a shallow $\mathrm{N}-\mathrm{S}$-aligned ditch containing shell fragments, burnt clay, small pieces of slag and a small number of unidentifiable fishbone fragments. To the north-west was a narrow gully containing patches of mussels.

\subsection{Phase 3: enclosure (10th-11th centuries AD) (illus 3c)}

This phase of activity on the site is represented by a large ditch and a pit, both of which cut through the earlier Phase 2 building and enclosure.

\subsubsection{Ditch}

The most substantial feature uncovered during the excavation was a large curvilinear ditched feature, a $12 \mathrm{~m}$-long stretch of which was exposed in the floor of the trench at the eastern end of the site (illus 8). The ditch measured some $1.5 \mathrm{~m}$ wide and $0.4 \mathrm{~m}$ deep, with a concave base. The fill contained cockle, buckie and otter shells in the upper level and large lumps of smelting slag and lumps of bog iron ore in the basal fill. A stone disc with one slightly convex surface was also recovered from this fill. 
Table 1 Radiocarbon dates

\begin{tabular}{lcccr}
\hline Lab No & BP & $\begin{array}{c}\text { Delta-13C } \\
(\%)\end{array}$ & $\begin{array}{c}\text { Calibrated Dates } \\
\text { 1 sigma }\end{array}$ & $\begin{array}{c}\text { Calibrated Dates } \\
\text { 2 sigma }\end{array}$ \\
\hline OxA-9349 & $1139 \pm 37$ & -24.8 & $\mathrm{AD} 880-980(67.3 \%)$ & $\mathrm{AD} 780-990(95.5 \%)$ \\
OxA-9350 & $513 \pm 31$ & -23.3 & $\mathrm{AD} 1407-34(68.2 \%)$ & $\mathrm{AD} 1390-1450(87.8 \%)$ \\
OxA-9351 & $1121 \pm 35$ & -24.1 & $\mathrm{AD} 890-980(68.2 \%)$ & $\mathrm{AD} 810-1000(93.6 \%)$ \\
OxA-9352 & $1129 \pm 33$ & -23.6 & $\mathrm{AD} 910-980(56.6 \%)$ & $\mathrm{AD} 810-1000(93.1 \%)$ \\
OxA-9353 & $1247 \pm 32$ & -23.0 & $\mathrm{AD} 690-810(63.8 \%)$ & $\mathrm{AD} 680-890(95.4 \%)$ \\
OxA-9513 & $1055 \pm 55$ & -22.9 & $\mathrm{AD} 940-1030(53.5 \%)$ & $\mathrm{AD} 870-1070(88.7 \%)$ \\
\hline
\end{tabular}

\subsubsection{Pit}

Cut through the east edge of the Phase 3 ditch and through the flagstone threshold of the Phase 2 building was an oval pit measuring $1.75 \mathrm{~m}$ by $1.0 \mathrm{~m}$ and $0.4 \mathrm{~m}$ deep. The upper fill comprised laminated silts and sands with cockle shells, fragments of animal bone and a piece of slag. Further environmental analysis yielded concentrations of cereal grain, chaff fragments and weed seeds (see Plant report below). Grains of barley and rye were predominant, with a smaller concentration of black oat and weeds common to cultivated fields also present. Interestingly, there was also a large concentration of heather, indicative of heaths and moors, probably collected for use as thatch, flooring or bedding material, and small fragments of hazelnut shells, either collected for food or accidentally brought to the site with firewood. A bone-weaving tool, possibly of sword-beater-type and widely known from AngloSaxon sites, was recovered from the fill (see Artefacts report below). The lower fills comprised bands of charcoal separated by bands of silty sand.

\subsection{Phase 4: medieval features (15th century AD) (illus 3d)}

The only medieval feature was a small rectilinear cut, possibly a hearth, packed full with charcoal, slag, hammer-scale, a fragment of furnace or crucible wall, cockle shell, a hazelnut shell, two iron nails, both with a circular head, and a possible iron saw blade. The hazelnut shell provided a radiocarbon date (OxA-9350) in the 15th century AD.

A thick, homogeneous deposit of possible cultivation soil was extensive across much of the site. It progressively thinned out towards the south, and on average measured between $0.55 \mathrm{~m}$ and $0.75 \mathrm{~m}$ in depth, but in places reached $1.1 \mathrm{~m}$. This deposit was largely recorded from sections exposed during construction. An assemblage of predominantly medieval and post-medieval finds was recovered from this layer, most of it off-site, by a local metal detectorist, as this soil was dumped on an adjacent field to create a bund. Other than a few finds handed to the excavation team, these finds were submitted sepa- rately to Treasure Trove and are not reported on here; they included coins, tokens, brooches, buckles, buttons, pins, a bone counter, a mirror case, pottery, a leather shoe sole, glass, slag, bog iron, burnt clay, animal bone, shell, fish bone and clay pipes. The pottery recovered included three sherds of East Coast Redware and two sherds of Yorkshire ware, which suggests a 13th- to 14th-century date for the earliest working of these soils, with activity clearly continuing through to at least the 17th century. There were, however, finds of potentially early medieval date, including one sherd of coarse pottery, a whale bone counter and a decorated copper alloy bell, in addition to the range of ironworking debris found during the excavation reported on here.

\subsection{Radiocarbon dates (Table 1)}

Six samples were submitted to the Radiocarbon Accelerator Unit, Oxford University. The dates are uncalibrated in radiocarbon years BP (Before Present-AD 1950) using the half life of 5,568 years. Calibrated dates referred to in the 'stratigraphic text' and 'discussion' have been calculated using the Oxcal computer program (v3.3) of C Bronk Ramsey (1995), using atmospheric data from 'INTCAL98' (Stuiver et al).

\subsection{The pottery Derek W Hall}

This watching brief produced 30 sherds of pottery (Hall 2000). Other than two unidentified sherds, all the pottery was unstratified or recovered from topsoil stripping; the assemblage comprised 15 sherds of East Coast Redware, 6 sherds of Yorkshire Ware, 3 sherds of White Gritty and 4 modern sherds. The assemblage would seem to date to the 13 th or 14 th century as there is certainly nothing present to suggest a later date. The redware fabric (15 sherds) is, however, of interest. This tradition of native pottery production apparently dates from the 13 th to the 15 th centuries (Hall, 1996, 126) but Dornoch material, although it shares many of the standard characteristics of this fabric, appears to 
be much grittier than normal. Ongoing excavations at Portmahomack are recovering a similar material from the medieval levels and there would appear to be the implication that an as yet unidentified production centre or centres for this fabric must exist somewhere in this part of the Highlands, slightly further north than previously assumed (Hall 1999, $17-19)$.

\subsubsection{Geochemical fingerprinting of Dornoch pottery \\ Simon Chenery}

Five samples of redware were analysed for a wide variety of elements by ICP-MS and the resulting geochemical fingerprint was compared with that of other Scottish redware previously analysed (Chenery 2001).

The samples from Dornoch seem to divide into three groups on the basis of their geochemical fingerprints (Dorn 1-5). One group (Dorn 2 and 4) has a fingerprint that is clearly related to that of the Elgin/ Spynie group of redware samples. Unfortunately, three samples (Dorn 1, 3 and 5) appear to have fingerprints with similarities to different groups depending on the statistical method employed, therefore we cannot currently assign them to any of the previously analysed groups. It is, however, suggestive that they may form two 'new' groups of samples.

\subsection{The artefacts Adrian Cox}

The finds span a wide date range, reflecting longterm activity on the site or in its vicinity, from the early medieval period until recent times. Unfortunately, few finds were recovered from stratified contexts, most being from the extensive cultivation soil deposits or from unstratified contexts (Cox 2000). Some of these unstratified finds are high status and are contemporary with the excavated remains and have therefore been included in this paper (illus 6).

\subsubsection{Copper-alloy objects}

A diverse range of copper-alloy artefacts was recovered, although all apart from No. 11 (a perforated sheet fragment, not illustrated) are from unstratified contexts.

\section{Bell. Surviving height $30 \mathrm{~mm}$; max. width $21 \mathrm{~mm}$}

No. 1 is a clapper bell of faceted conical form, with a trapezium-shaped suspension loop. Its full height does not survive, as it is broken above the rim. The surface is decorated by ring-and-dot motifs, especially in a zone immediately above the broken edge.

Parallels for this bell come from Norse contexts, for example in Keoldale, Sutherland and Iceland. A fine example, surviving more completely than the Dornoch bell, was found at Freswick Links (Batey 1988). This bell has very similar faceting and decoration, and incorporates small, downward projections, equally spaced around its rim; elements which may originally have been present on the Dornoch bell.

No. 1 has an internal wire loop at its apex, indicating that it had a clapper. Some bells, though, including an example from North Elmham Park, Norfolk, had no provision for a clapper or a pea, and possibly rang by clashing with other bells (Goodall 1980, 504).

Whilst rumbler bells containing loose 'peas' were worn as dress accessories, on horse harness and on the collars of pets and hunting dogs in the medieval period, earlier clapper bells such as this one may have had a slightly different range of functions. While some are interpreted as harness bells, others may have served an ecclesiastical function. Biddle and Hinton (1990, 725) note that bells of this size were used as mass bells from the 13th century onwards.

Open bell of six-faceted, tapering form, broken above the base. At the apex is a trapezium-shaped suspension loop, with a small, circular perforation. Internally, remains of a wire loop for suspension of the clapper survive, although the clapper itself is missing. Decorative ring-and-dot motifs are visible on the exterior surface, below the apex and immediately above the broken edge, although much of the decoration is obscured by corrosion products.

Unstratified; Find No. 8

2 Brooch fragment. Length $18 \mathrm{~mm}$; width $7 \mathrm{~mm}$; thickness $1 \mathrm{~mm}$

No. 2 is part of the frame of an annular brooch, broken across the recess in the frame about which the brooch pin pivoted, and transversely across the frame. Both faces bear incised decoration. On one face this consists of a repeating zig-zag-type design, within a border or panel. The design on the opposite face is less regular and resembles the tail of a fish, although this may also be part of a repeating pattern. Brooches of this type are described by Callander $(1924,169,179)$ as flat ring brooches, and he catalogues examples of copper-alloy, silver and gold. Examples of similar form to that of No. 2 are generally dated by Callander to the 14 th century, although he notes that this type of brooch remained popular in Scotland until the latter part of the 18th century, when larger and broader examples were fashionable (ibid, 178). Although none closely parallels the Dornoch example, a group of annular brooches was among the assemblage recovered from Urquhart Castle between 1912 and 1922 (Samson 1982, 573, Fig. 6, No.s 82-3).

Fragment of an annular brooch (projected external diameter $c$ 35-45mm), with a recess in the frame about which the pin pivoted. The frame is of sub-rectangular cross-section. Incised decoration appears on both faces.

Unstratified; Find No. 32

3 Buckle. Length (including pin) $26 \mathrm{~mm}$; surviving width $17 \mathrm{~mm}$; thickness $6 \mathrm{~mm}$

Only a single buckle is represented. No. 3 is a fragment of a small buckle with an integral plate. Lacking its frame, this example is not closely datable on typological grounds, although buckles with integral plates appear to have been popular during the 13 th and 14 th centuries. Such buckles had a range of uses, including fastening spurs and a variety of clothing.

Part of a buckle with an integral buckle plate, including the pin. The buckle plate, which has bevelled edges, is 

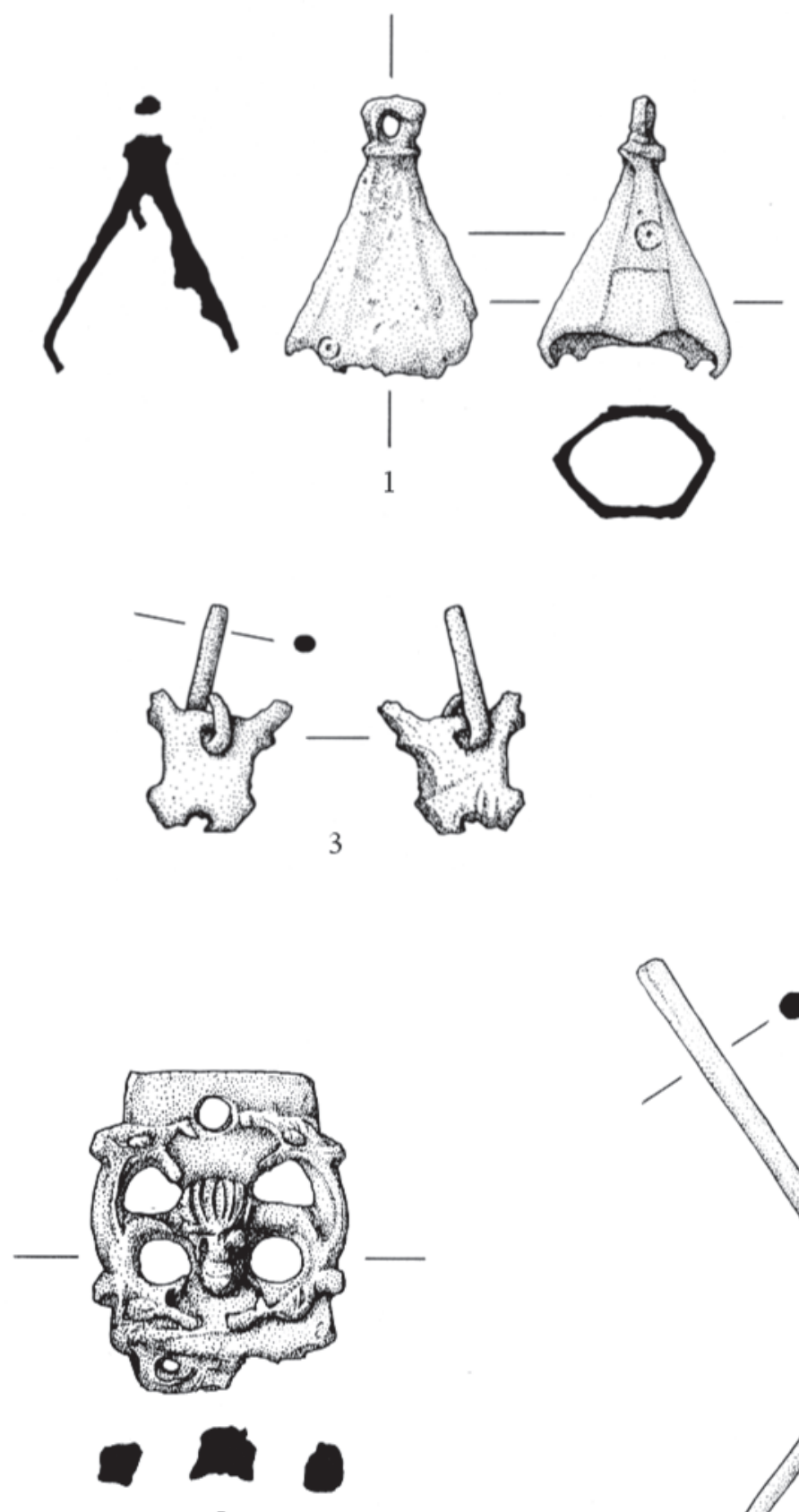

5

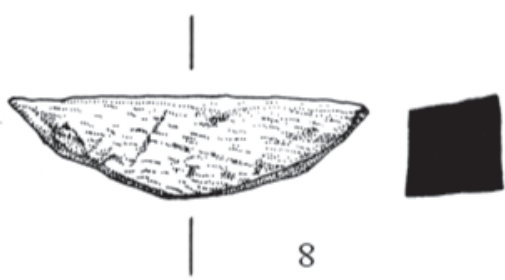

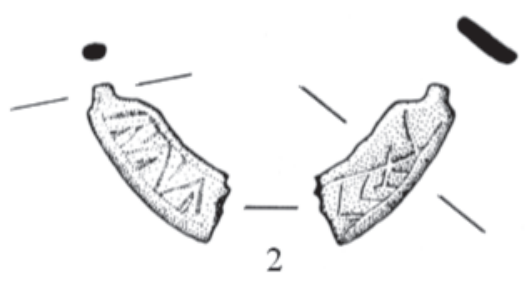
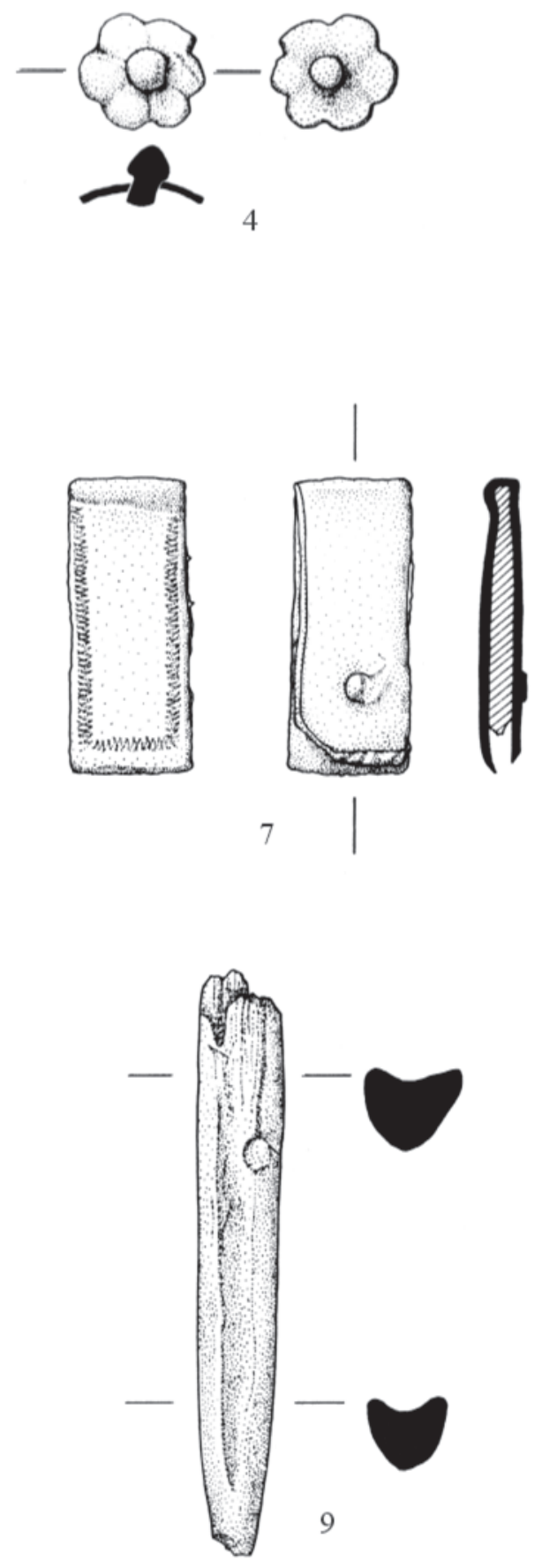

Illus 6 The artefacts 
broken across a centrally-positioned rivet hole. The frame of the buckle is almost entirely missing.

Unstratified; Find No. 13

4 Mount. Diameter 14mm; thickness (including rivet) $6 \mathrm{~mm}$

Sexfoil mounts like No. 4 are generally interpreted as decorative fittings on leather straps and clothing. Evidence from London confirms this, as examples have been found decorating perimeter tabs on a fragment of leather and lying equally spaced along a strap (Egan and Pritchard 1991, 192, illus 121, No.s 1028 and 1030). A variety of forms of sexfoil mounts, with different methods of attachment, has been recovered from London excavations (ibid, 186-192), and they appear to have been in common usage by the mid 14th century. Scottish examples of these flower-shaped mounts include sexfoil examples from Aberdeen (Stones 1989, 157, illus 96, No. 109) and Ayr (Cox forthcoming). An octofoil mount with embossed decoration was found at Tay Street, Perth (Cox 1994, 483, illus 9, No. 4). In comparison with these, No. 4 is smaller and less regular in outline.

Slightly concavo-convex mount of sexfoil form. The segments are of unequal size. A rivet with a domed head pierces the centre of the mount.

Unstratified; Find No. 25

\section{Mount. Length $36 \mathrm{~mm}$; width $28 \mathrm{~mm}$; thickness $7 \mathrm{~mm}$}

No. 5 is an openwork mount of zoomorphic design. Central to the design is a stag's head, with its antlers forming the sides of the mount. The mount was secured by means of three rivet or cord holes, one at the apex and two along the bottom edge.

Cast, openwork mount of zoomorphic design, with originally horizontal upper and lower edges (the lower edge is now broken). There is a centrally-positioned, circular perforation (diameter $4 \mathrm{~mm}$ ) at the top of the mount and two smaller perforations (diameter $2 \mathrm{~mm}$ ), one of which is broken, adjacent to the lower edge. The design in the centre of the mount may represent a stag's head and its stylised antlers form the curving sides of the object.

Unstratified; Find No. 35

A circular, discoid object (not illustrated) made from very thin sheet and perforated through its centre is also probably a mount. Small, lightweight mounts, including specific forms termed spangles, appear to have been sewn to clothing in the medieval period, and possibly worn in groups rather than singly.

6 Pin shaft. Length (if straightened) 94mm; max. diameter $3 \mathrm{~mm}$

The form of the terminal of No. 6 indicates that it is most likely to be the shaft of a pin rather than a needle. The top of the shaft, though not carefully finished, appears to represent a deliberate terminal rather than the site of a fracture, which would indicate that it is not a needle. Additionally, the upper $5 \mathrm{~mm}$ of the shaft is slightly discoloured in comparison with the remainder; a possible indication that this zone was covered or enclosed by a missing head. A strong possibility is that this shaft is from a large, globular-headed pin in which the upper $5 \mathrm{~mm}$ of the shaft was enclosed.

Tapering, circular cross-sectioned shaft, probably from a pin. It is bent at mid-shaft, and the head is missing.

Unstratified; Find No. 34
7 Strap end. Length $34 \mathrm{~mm}$; width $18 \mathrm{~mm}$; thickness $4 \mathrm{~mm}$

No. 7, made from a folded strip, was used on the end of a strap or cord. Its form and decoration indicate a probable medieval date. The type of incised zig-zag decoration appearing on this object is not uncommon on medieval belt fittings. Similar ornament appears on a buckle plate from Linlithgow (Stones 1989, 159, illus 99, No. 223), for example.

Rectangular strap end made from a folded strip. A rivet, positioned $8 \mathrm{~mm}$ from the open end, secures the two sides, and a fragment of textile appears to be enclosed. The edges of the upper face are decorated by an incised zigzag design.

Unstratified; Find No. 33

\subsubsection{Bone objects}

8 Disc fragment. Length $37 \mathrm{~mm}$; max. width 10mm; max. thickness $10 \mathrm{~mm}$

Two artefacts of bone (No.s 8 and 9) were recovered. No. 8, probably derived from whale bone, is a fragment from the edge of a discoid object, possibly a counter. It has not been finely finished, as it is of uneven thickness and exhibits paring marks on its outer edge. It may be of early medieval or medieval date.

Worked fragment probably derived from whale bone. It appears to represent part of a discoid object (projected diameter $c 45-50 \mathrm{~mm}$ ), of slightly uneven thickness. One surface has a smooth curvature and is pared. The opposite surface is straight and flat, but is probably the site of a fracture.

Context 2; Find No. 40

9 Weaving tool. Length 66mm; max. width $9 \mathrm{~mm}$; thickness $8 \mathrm{~mm}$

A probable weaving tool fragment (No. 9) was recovered from an oval pit which also contained an interesting assemblage of botanical remains, including heather, cereal grains and weed seeds (see The plant remains). The object appears to represent a weaving tool of probable early medieval date, although, given its fragmentary nature, an Iron Age origin cannot entirely be ruled out. It may have been residual in this context. Smooth, pointed tools like this one are necessities in fine weaving on hand looms, being used to adjust single threads or groups of threads, before and after a throw.

Small, cigar-shaped pin beaters are widely known from Anglo-Saxon sites, such as Harston in Leicestershire (Dunning 1952), and these tend to survive better than their larger counterparts, sword beaters, possibly because the latter may often have been made from wood (MacGregor 1985, 188). The two types performed complementary functions, the pin beater being inserted between individual warp threads and used at right angles to the plane of the weft, while the sword beater operated parallel to the weft (ibid). This example seems more likely to have performed a sword-beater-type role. The species identifications are by C Smith.

Probable weaving tool fragment, derived from a large ungulate long bone shaft (possibly from a bone such as a tibia). The object tapers at one end, although the tip is missing. The broader end is also broken. The surface is highly polished.

Context 48; Find No. 16 
Table 2 Features with dimensions and descriptions of fills

\begin{tabular}{|c|c|c|c|c|}
\hline Features & Phase & Type & Dimensions & Description \\
\hline C36 & 1 & pit & $0.6 \times 0.65 \times 0.6 \mathrm{~m}$ & $\begin{array}{l}\text { Vertical sides, flat base: charcoal flecks and packing } \\
\text { stones }\end{array}$ \\
\hline C30 & 1 & hearth/pit & $0.4 \times 0.35 \times 0.18 \mathrm{~m}$ & Concave base: signs of burning, burnt animal bone \\
\hline C32 & 1 & hearth/pit & $0.8 \times 0.7 \times 0.2 \mathrm{~m}$ & $\begin{array}{l}\text { Fill (C31): burnt/unburnt animal bone, charcoal, burnt } \\
\text { clay, shells }\end{array}$ \\
\hline C51 & 1 & post-hole? & $0.88 \times 0.48 \times 0.14 \mathrm{~m}$ & Concave base \\
\hline C57 & 1 & gully & $0.5 \times 0.3 \mathrm{~m}$ & $\begin{array}{l}\text { Upper fill (C56): charcoal, shells, fish bone, animal } \\
\text { bone, charred barley grain. Lower fill: furnace/hearth } \\
\text { lining, slag, iron }\end{array}$ \\
\hline $\mathrm{C} 23$ & 1 & spread & $0.1-0.3 \mathrm{~m}(\mathrm{deep})$ & Smelting slag, tuyere \\
\hline $\mathrm{C} 14$ & 1 & hearth & $1.6 \times 0.8 \times 0.2 \mathrm{~m}$ & $\begin{array}{l}\text { Vertical sides: burnt sand/shells, charcoal frags, fire- } \\
\text { cracked stones }\end{array}$ \\
\hline $\mathrm{C} 18$ & 2 & ditch & $0.35 \times 0.2 \mathrm{~m}(\mathrm{deep})$ & $\begin{array}{l}\text { Fill (C17), concave base: dark sand, shells, animal } \\
\text { bone, slag, charred grains of barley }\end{array}$ \\
\hline $\mathrm{C} 20$ & 2 & ditch & $0.8 \times 0.15$ & $\begin{array}{l}\text { Fill (C19): sandy silt, burnt clay, slag, fish bone } \\
\text { fragments }\end{array}$ \\
\hline C45 & 2 & midden & $1.75 \times 0.75 \times 0.07$ & $\begin{array}{l}\text { Bog ore, charcoal, slag, burnt bone, shells, charred } \\
\text { barley and oat grains }\end{array}$ \\
\hline $\mathrm{C} 25$ & 2 & $\operatorname{ditch}$ & $0.65 \times 0.2 \mathrm{~m}$ & $\begin{array}{l}\text { Fill (C24): sand, animal bone shells, charcoal, charred } \\
\text { oat and hulled barley }\end{array}$ \\
\hline $\mathrm{C} 42$ & 2 & ditch & $0.40-0.45 \times 0.4 \mathrm{~m}$ & Fill (41): slag \\
\hline $\mathrm{C} 44$ & 2 & ditch & $0.25 \times 0.2 \mathrm{~m}(\mathrm{deep})$ & Fill $(\mathrm{C} 43)$ \\
\hline C52 & 2 & layer flat stones & $3.0 \times 1.75$ & $\begin{array}{l}\text { Fill (C53), packing consisting of: shells, charcoal, slag, } \\
\text { charred barley }\end{array}$ \\
\hline C59 & 2 & hearth/pit & $0.95 \times 0.65$ & $\begin{array}{l}\text { Fill (C58): charcoal, furnace/hearth lining, shell, } \\
\text { barley grains, iron objects }\end{array}$ \\
\hline $\mathrm{C} 27$ & 3 & ditch & $12 \mathrm{~m} \times 1.5 \times 0.4 \mathrm{~m}$ & Fill (C26): shells, slag and bog ore \\
\hline C49 & 3 & pit/hearth & $1.75 \times 1 \times 0.4 \mathrm{~m}$ & Fill (C48): shells, animal bone, single slag fragment \\
\hline C39 & 4 & hearth/pit & $0.42 \times 0.54 \times 0.2 \mathrm{~m}$ & $\begin{array}{l}\text { Fill (C38), concave base: charcoal, slag, shells, iron } \\
\text { nails and blade, hammer scale; Fill (C40): hammer } \\
\text { scale and shells }\end{array}$ \\
\hline
\end{tabular}

\subsection{Metallurgical wastes analysis E Photos-Jones}

\subsubsection{Introduction: setting the scene}

This section aims to assess the nature, composition and distribution of the metallurgical waste derived from the watching brief/excavations at Meadows Business Park, Dornoch as a means of shedding light on the iron-making and -working practices in the east of Scotland in the periods between the 8th and 15th centuries AD (Coleman 1997 \& 2000; Photos-Jones 1999a). This report summarises the results of the analysis of the materials recovered from the site; the technical analysis is reported on separately (Photos-Jones 1999, 1999a \& 2000). The limited scale of the 1997 excavations revealed a number of features to include pits, gullies, hearths, middens and ditches spanning four phases: 1 (8th9 th centuries), 2 (9th-10th centuries), 3 (10th-11th centuries), 4 (15th century). All phases were covered by a cultivation soil (Context 2) rich in medieval and post-medieval artefactual evidence. Illus 3a-d shows the site plan as per individual phases and Table 2 presents feature dimensions, typology and the nature of their fills consisting of slag, shells, animal bone, charcoal etc or a combination thereof.

This section also attempts to address - but does not necessarily resolve - the issue of how to interpret sites dating to the late first millennium $\mathrm{AD}$ which a) are not particularly rich in finds, b) are characterised by varying amounts of metallurgical waste and c) reveal the range of features mentioned above. Gullies in the vicinity of furnaces have often been interpreted as windbreaks or open-fronted working sheds (F Walsh, pers comm; C Spall, pers comm). Although this is certainly a plausible interpretation, it takes into account only some of the features present, leaving the rest unexplained. In addition, there are currently no objective grounds by which to approach their interpretation. In other words, one excavator's 'pit' is another excavator's 'bowl furnace' or a third excavator's 'hearth', the interpretation of each feature relying heavily on subjective criteria. 
In an attempt to redress this balance, it is suggested here that recording these features in a tabular form like that shown in Table 2 , ie according to shape and dimensions, number and type of fills may be useful and may ultimately lead to the realisation that a features typology does exist and perhaps is shared by a number of sites. Dornoch is by no means unique. Indeed, this author has examined a number of such sites, primarily in Ireland, dating to the end of the first millennium $\mathrm{AD}$, where metal-making/working activities appear to have constituted an integral part of the domestic activities on site. At Killickaweeny in Co. Westmeath (9th-10th centuries $\mathrm{AD}$ ), excavations revealed a variety of gullies and pits in association with hearths and bowl furnaces (Photos-Jones 2004). At Portmahomack, to the south of Dornoch and contemporary with it, excavations revealed a number of 'features, small round bowl furnaces and hearths, which are defined quite crudely with curvilinear gullies' (C Spall, pers comm).

What these sites possibly suggest is that metalmaking/working took place within or in the immediate vicinity of the domestic areas, to include areas where food might have been prepared and consumed. The above suggestion, if indeed true, takes iron metallurgy in the first millennium $\mathrm{AD}$ - and perhaps earlier - out of its conventional framework of an expert-based craft, practised by the select few, and integrates it into the multitude of everyday gender-based activities on a par with food supply and preparation. Identification of the 'locus' of these activities and the understanding of their nature rests inevitably with the interpretation of the function of the diverse pits and hearths, ditches and gullies which currently elude us.

In this section a background into bloomery iron-making is briefly outlined, followed by the presentation of data on ores, metallurgical ceramics, slags and fragments of bloom. The discussion highlights the observation that the 1997 excavations revealed an area of continuous but low-intensity metalworking activity over a period of at least 200 years, merging quietly with other equally low-intensity domestic 'chores'. The fact that a furnace/hearth appears to have been set up in the 15th century in the immediate vicinity (Context 39) is perhaps a testimony to the 'reluctance to change' nature of these sites.

\subsubsection{The site}

Table 2 lists features/contexts by phase. Thus for Phase 1 the contexts with slag and other materials (bone, shells, charcoal) include Context 57; contexts with materials other than slag: contexts $14,30,32$, 36 and 57; contexts with slag only: Context 23. In Phase 2 the contexts with slag and other materials include contexts 18, 20, 45, 52 and 59; contexts with materials other than slag: Context 25; contexts with slag only: Context 42 . In Phase 3 the contexts with slag and other materials include contexts 27 and 49. In Phase 4, the contexts with slag only include Context 39. From the above, it is clear that while for Phase 1 the majority of contexts contain materials other than slag, in Phase 2 the majority of contexts contain slag in association with other materials. Phase 1 and 2 contexts overlap or at best lie in immediate proximity to each other. The above 'pattern' suggests an area, part of a larger settlement where the activities dedicated to metalmaking/working are localised and of low intensity over a long period of time.

Having dealt with the fills of the individual contexts, attention is now turned to the nature of the features and the possibility of classifying them according to shape/size. Context 30 (Phase 1) and Context 39 (Phase 4) are oval/sub-circular with a concave base and signs of burning. While slag, hammer scale etc are evident in Context 39 they are absent from Context 30. Similar pits would be classified as bowl furnaces with or without evidence for oxidised clay lining. Context 32 (Phase 1) may belong to the same group, as indeed could Context 59 (Phase 2), while Context 51 (Phase 1), labelled a posthole, is unlikely to have such a function. Context 14 (Phase 1) and Context 49 (Phase 3) are considered hearths on account of their rectangular dimensions. Their identification as domestic or metallurgical, or perhaps even both, probably lies in their placement within the larger framework of the site.

\subsubsection{About bloomery iron-making}

Scotland is richly endowed with iron ore deposits which have been considered both from a geological (McGreggor et al 1920) as well as an archaeological perspective (Hall and Photos-Jones 1998, Part 2 ). Prior to the early 17 th century, exploitation was small scale and associated with iron seepages or encrustations (bog iron ores) characterised by the presence of manganese and phosphorus and low potassium and calcium contents (ibid). The use of these regenerative sources of iron ore - they can re-form at a considerable thickness over a period of $c 30$ years - was first studied in association with the post-medieval bloomery mounds of the Scottish Highlands (ibid, Table 1). The fragments of bog iron ore at Dornoch clearly point to the type of ore used, but the source of this ore remains elusive. Nevertheless, to the south of the firth there is reference to 'Allt na main' (the iron burn) (C Miller, pers comm) and it is highly likely that these bright orange claylike seepages would be the most accessible sources of iron ore compared to the bog ores lying under layers of peat. Overall, and despite oral tradition for 'red burns', there is surprisingly little understanding of the difference between the manganiferous ores and their orange clay-like counterparts, rarely visible in an archaeological context on account of their clay-like and pasty texture. In other words, our view of what constituted bog ore(s) at the time 
may be different from that of the ironsmiths at Dornoch.

Presently, the earliest bloomery furnace in Scotland is thought to be the one excavated at Tarras Farm, Forres, near Inverness, dated to cal 198 BC-AD cal 49 and cal 378 BC-AD cal 17 (Will 1999; Photos-Jones 1999b). It was a simple bowl-type furnace dug into the ground and lined with stone slabs, and probably covered with a clay/charcoal superstructure to ensure prevalence of oxygenpoor conditions, leading to the effective smelting of the ore. The product was workable low-carbon iron for most uses.

Despite its antiquity, the bloomery is a chemically complex process involving the reaction of a solid lump of ore (iron oxide) with carbon monoxide from the burning of the fuel (charcoal). As such, the process is difficult to control, yields are uncertain, and furthermore, a large amount of iron is lost in making slag, the non-metallic component or waste. Metal artefacts in the form of raw metal or finished objects are a rare occurrence in bloomery sites, but occasional finds do shed light onto what the end product, the bloom, might have been: essentially a low-carbon malleable iron, wrought iron, which could be shaped into any tool, weapon or decorative artefact. A fragment of a bloom was found amidst the Dornoch collection but was unstratified (Context 2).

Bloomery slags have been traditionally classified as 'tapped' and 'non-tapped' on the basis of the method of their removal in the course of the smelting operation. When tapped they acquire their characteristic drop-like surface texture. When non-tapped they tend to accumulate around the bloom and/or drip from it, ending up as small/large lumps at the furnace floor or when the smelt has been largely unsuccessful, as furnace bottoms. This is the nontapped type of slag which forms the majority of the $c 12 \mathrm{~kg}$ of fragments recovered from all periods from the site.

Smelting and smithing slags have been traditionally differentiated on the basis of their morphology, primarily the presence or absence of smithing hearth bottoms, but this is at best a first-level classification. Among the Dornoch metallurgy waste there is relatively little evidence for smithing slag proper, which in any case would have made up a small percentage of the total compared with smelting and bloom smithing slag. Chemically, slags of the smelting or smithing type are iron-rich (with up to 60-70\% iron oxide), crystalline, spongy, dense and brown-black in colour. Such high percentages of iron in the waste product testify to the inherent inefficiency of the bloomery. Mineralogically, smelting and smithing slags tend to be similar in that they contain wustite (iron oxide) and fayalite (iron silicate). But other phases like hercynite (iron aluminium oxides) or iron manganese silicates can only form in the smelting process, and their presence in the slag can only characterise them as being of the smelting variety. Furthermore, characteristic fingerprinting elements like barium can also point to primary processes. Overall, apart from mineralogy and chemical make-up, corroborating evidence from metallurgical ceramics such as fragments of tuyeres, furnace wall or lining, hearth walls etc is needed to confirm that smelting and smithing were taking place side by side, and there is certainly such evidence at Dornoch.

\subsubsection{Conclusions}

From the data presented in Table 2 it is suggested that a low-intensity metal-making/working activity took place at that 'corner' of the settlement over a prolonged period of time. The raw materials and products of all stages in metal-making/working are represented here: bog ore, bloom/billet, slag and iron artefacts, although without representative examples from each period. Although the products of these activities are clear and manifested via the $c 12 \mathrm{~kg}$ of metallurgical waste, the nature and identity of the features that contained them either on their own or in association with other materials - food stuffs and fuel ash and waste - is less clear.

\subsection{The faunal remains Catherine Smith}

Remains of mammals, fish and marine mollusca were amongst the finds that were recovered from the site by hand excavation, but most were either unstratified or from the cultivation soil. The mammal remains were mainly those of domestic animals (cattle, sheep, pig, horse and dog), although one bone from a marine cetacean, a medium-sized whale, was also recovered. On the basis of the fragment count of the hand-excavated sample, the most common mammalian species found at the site were cattle (35 fragments), and sheep (two partial skeletons and 12 fragments from other individuals). Pig and horse bones were not so numerous as those from either sheep or cattle. A single bone from a dog was also recovered.

\subsubsection{Marine resources}

The most notable find of animal origin was the cetacean vertebra (Context 56). This had been chopped through the centrum in a dorso-ventral direction, and also showed evidence of hack marks both on the lateral aspect of the centrum and near the surviving neural spine. It has not been possible to identify the species of whale which this bone represents, but on size indications the animal was larger than a pilot whale and smaller than, say, a sperm whale. It probably represented a beached animal found on the shore of the Dornoch Firth. Whale meat, bones and other by-products were utilised by coastal dwellers in all parts of Scotland 


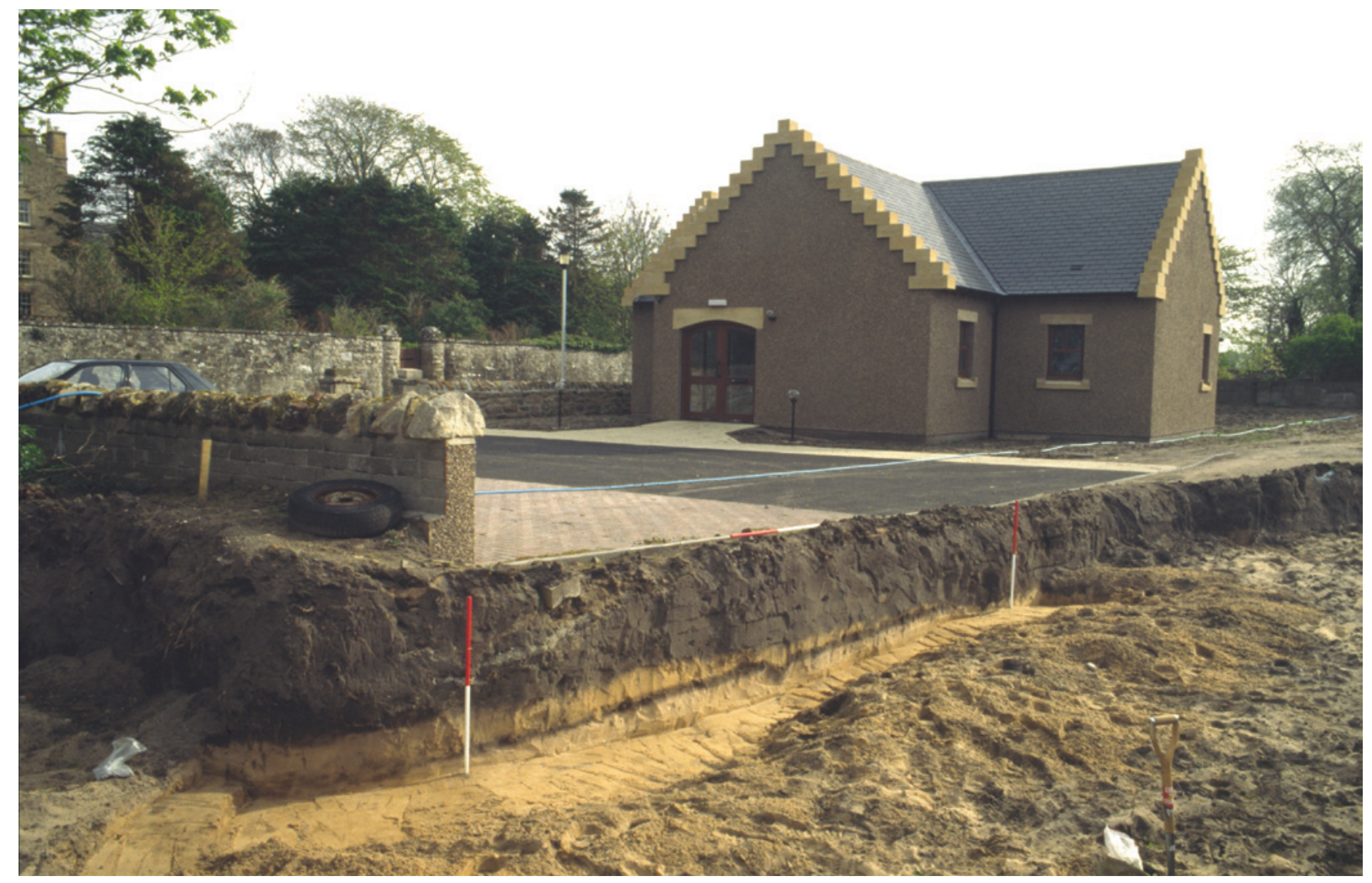

Illus 7 Section through cultivation soil

from the earliest times, and a chance stranding may have provided a welcome addition to the diet, as well as being a valuable source of raw material. It is notable that a broken bone artefact recovered from the sieved residues was also cetacean in origin (Context 2; Sample 1). The artefact was compared with modern specimens of both red deer and reindeer antler as well as a dorso-ventral section of mandibular bone from a Greenland right whale (Baleana mysticetus). The pattern of pores in the surface of the object was almost indistinguishable from that of the outer (cortical) layer of the whale bone sample, indicating its most likely origin.

Other marine resources were also exploited: a small number of fish bones were recovered, as well as shells of marine mollusc. The fish bones came from haddock as well as members of the gadid family, which includes cod, ling, saithe and pollack (Cerón-Carrasco 2000). The marine mollusc shells all came from edible species: common periwinkle or whelk (Littorina littorea), buckie (Buccinum undatum), cockle (Cerastoderma edule), mussel (Mytilus edulis), limpet (Patella sp.) and common otter shell (Lutraria lutraria). Shells were particularly numerous in the sieved samples. Although it is probable that the shells were the remains of processing for food, they may also have been used for fishing bait. It is notable that the most abundant mollusc species was the cockle, which is more palatable to humans than the limpet, a far less common species in the Dornoch assemblage. Limpet flesh is fairly tough and it was common in Scottish fishing communities for the women to chew the flesh to a soft consistency before baiting the lines with them. In addition, some of the mollusc shells may have been imported to the site along with seaweed intended as agricultural fertiliser.

Some of the mollusc shells recovered from sieving of the ditch fills on the site were subjected to X-ray diffraction analysis (XRF) in order to ascertain whether they had been used in industrial practices involving the production of iron ore, but this was found not to be the case (PhotosJones, archive report). There was, however, some evidence that they had been subjected to heat (ibid), perhaps as a result of coming into contact with the residues from iron production, although their gross structure and appearance were not noticeably affected.

\subsection{The plant remains Mhairi Hastie}

Twelve soil samples were subject to environmental analysis, the majority of which contained fragments of charcoal and occasional charred cereal grains identified as hulled barley and oat. One sample from a pit fill (Context 48) did, however, stand out due to the concentration of cereal grains (Hastie 2000). The 
majority of the samples (contexts $2,11,17,28,31$, $40,45,53,56$ and 58) were removed from a series of ditch and pit features. The samples were dominated by metal-working debris, implying that the area was used principally for industrial activities. In addition, small quantities of cereal grain, primarily hulled barley with occasional oat, were recovered. Both of these crops are typical of this part of Scotland for this period and the site fits into a well-established pattern for the east of Scotland (Boyd 1988). The low concentration of grain in many of the features is a common observation on medieval sites and is probably indicative of small-scale domestic activities occurring on or near to the site.

\subsubsection{Pit 49}

One sample was removed from a pit (Context 48) in Phase 3 (10th-11th centuries AD). The pit was filled with a series of laminations that contained a concentration of cereal grain, chaff fragments and weed seeds. The assemblage contained a substantial quantity of cereal grain mixed with chaff fragments and a small quantity of weed seeds. Rye (Secale cereale), hulled barley (Hordeum vulgare) and black oat (Avena strigosa) were all present. The ratio of grain to chaff seems to indicate that the rye may have been charred at a different stage to the barley and oat. Only small amounts of chaff fragments were recovered for the latter species, yet $45 \%$ of the identified rye elements were chaff. This would tend to suggest that this cereal might have been charred while still on the ear. The concentration of grains is such that some sort of accident concerning bulk corn drying or burning of a store/building occurred.

\subsubsection{Significance of the cereal remains}

Three of the primary medieval cereal crops are represented with hulled barley, rye and oat all being present. Documentary evidence for this area suggests that oat, especially black oat, and barley or bere were the most commonly cultivated crops (Bethune 1793). The recovery of a large concentration of rye from Dornoch is therefore very significant. Cultivation of rye tends to be confined to areas of poor-quality land, as it is usually less profitable when grown on good soils compared to other cereal crops. It can, however, fare better on dry and light land or upland marginal arable areas that produce inferior crops of oats, barley and wheat (Watson and More 1962). Occasionally it was also grown as part of a mixed crop sometimes with barley and oats, or as a maslin with wheat. This would generally produce a higher yield of grain than would be obtained from cultivating species separately (Grant 1995).

The presence of a large concentration of rye at Dornoch may, therefore, reflect the initial increase in the cultivation of these marginal areas and improved farming techniques. Rye can be cultivated for both its grain and its straw; the grain is used in the making of rye bread and a variety of beverages (Chambers and Jones 1984). Rye may also have been grown specifically for thatch or packing purposes, as the straw is much longer, stronger and wears better than other cereal straw (Watson and More 1962). In some areas it was grown for animal consumption (Green 1981). The 'native' varieties of rye were more leafy and suitable for winter sowing, which would produce a spring crop that was very appropriate for use as fodder or foliage. It was not until after the Second World War that new, improved grain varieties of rye were introduced from the continent (Watson and More 1962).

The archaeological assemblage from Dornoch does not enable us to distinguish between these three uses, primarily because it seems to have been burnt while still in the ear. It does, however, open up the possibility that what we are seeing here is evidence for cultivation of marginal land, or for the growing of specialised crops destined for specific purposes such as fodder or thatching. Either way, this find is of considerable interest and adds to our understanding of agricultural development in medieval Sutherland.

\subsubsection{Wood charcoal identifications}

Three samples were examined. The most common components were alder (Alnus sp.), birch (Betula sp.), hazel (Corylus sp.) and willow (Salix sp.). In addition, small quantities of oak (Quercus sp.) and heather (Calluna/Erica sp.) were also recovered. All species present could have grown locally within the area and indicate that local woodland and heath were being exploited. Most of the taxa represent small scrub species and a large percentage of the charcoal suggests that branches and small twigs were predominantly utilised. Nevertheless, the presence of alder and oak implies that larger wood species were also being used occasionally, and the presence of large amounts of alder within Context 58 may be of some significance. Small fragments of charred bark were frequently recovered. Unfortunately, bark lacks detailed tissue structure and thus cannot be identified to species level. 


\section{Discussion}

Despite the circumstances and the limited area available for investigation - essentially a watching brief on an access road which evolved into a rapid salvage excavation - the results have established activity, especially metalworking, in the 8th-11th centuries $\mathrm{AD}$ to the south of the area later developed in the medieval period as the Cathedral and Bishop's Palace complex.

However, what is not clear as yet is whether the settlement and/or semi-industrial activity unearthed at The Meadows Business Park is Norse or Pictish/Gaelic. Place-name evidence is especially useful here and there has been much work done in the field of linguistics (Watson 1926; Nicolaisen 1976; Fraser 1986; Crawford 1995b; Bangor-Jones 1995, for example). The place-names of both Picts and Norse intermingle in what must have been a zone of contact between the two peoples, with a later Gaelic element being introduced as Pictish power declined in the ninth century (Fraser 1986, 23). Pictish place-names indicating settlement are relatively infrequent around the Dornoch Firth, Norse names more common and distributed fairly evenly, and Gaelic names represent by far the largest proportion of the settlement place-names in the area (Fraser 1986, 23-29).

The distribution of Viking graves also fits well with the place-name evidence, with a concentration around Dornoch (McNeill and MacQueen 1996, 645, 71; Batey 1993, 148-172). There is also a strong relationship between grave finds and the location of the best arable land - in north-east Caithness and the Dornoch area of Sutherland (Crawford 1987, 118). Some of the finds recovered from the cultivation soil at Dornoch (the finger bell, pinshaft and bone counter) and the one diagnostic find from the excavation (the bone pin beater) point to a Norse presence. The copper alloy bell, for example, has parallels from sites such as Freswick Links and Icelandic sites; the bone pin beater has both AngloSaxon and Norse parallels. The large numbers of cockle and mussel shells also have Norse parallels. Although it is not clear at Dornoch whether they were being used as food or bait, similar assemblages have been found at late Norse farms such as those at Jarlshof, Sandwick and Freswick and interpreted as

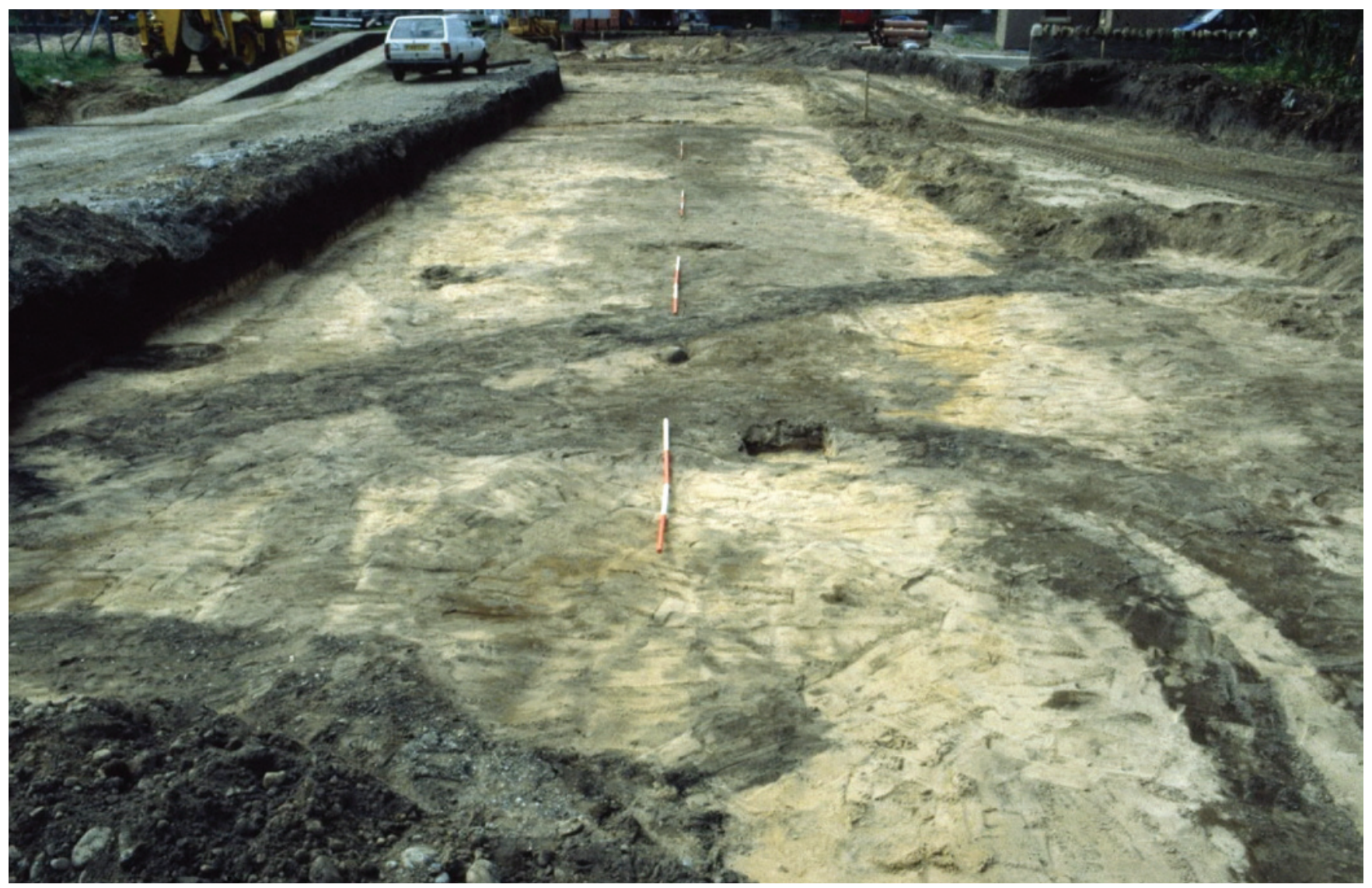

Illus 8 The access road under excavation looking west. The building is in the foreground and is cut by the ditch running diagonally across the trench 
being indicative of intensive fishing (Ritchie 1993, 122-124).

However, the early dates attributed to the activity at Dornoch would lend some support to the ageold tradition of a cell of Early Christian monks at Dornoch, and it is possible that the features uncovered at the Meadows Business Park represent a semi-industrial zone lying at the outer edge of a precinct around an early church complex. Phases 1-3 (8th-11th centuries $\mathrm{AD}$ ) all suggest that iron-making and -working were core activities, with evidence for all stages of the process present, a common feature of early monastic estates.

Remarkably few secular dwellings dating to the period from the 8th-11th centuries $\mathrm{AD}$ have been excavated on mainland Scotland, and most of the parallels for the enclosures, structures and activities carried out at the Meadows Business Park come from ecclesiastical sites. The nearest such site is at Portmahomack, just over the Dornoch Firth (Carver 2004). Excavations there in Sector 1, Intervention 25 (Sector 1 lies to the south of the early church), revealed somewhat similar structures and features (Tarbat Discovery Programme Bulletin No. 4 1998). These were interpreted as an oval enclosure, open at one end and $c 15 \mathrm{~m}$ along its long axis. This in turn overlay an earlier ditch, forming a curvilinear enclosure. Immediately to the south-west of these features was a group of intercutting gullies and postholes which appear to define a sequence of structures. Unfortunately, no finds were recovered from these features, which lay just outside the enclosure around the 8th-century monastery. Initially thought to be prehistoric in date, ongoing post-excavation analysis, however, now suggests that these features are more likely to be 8th-11th century in date and could be Norse (Tarbat Discovery Programme Bulletin No. 5 1999). Iron-making and -working were also features of Portmahomack during this period (ibid).

Further afield, parallels can also be drawn with the early monastic site on Inchmarnock, off the island of Bute, Argyll (Lowe, forthcoming). Here, within an enclosure, was a series of post-built huts, at least one of them associated with metalworking activity, a later phase of which was dated to cal $\mathrm{AD}$ 810-1020.

Ironworking in the 8th-10th centuries $\mathrm{AD}$ was not, however, confined entirely to monastic sites. An intriguing site at Upper Gothens, Perthshire, radiocarbon-dated to this period, consisted of a roughly circular enclosure visible as a cropmark. The interior had been badly damaged, but smithing slag and iron were recovered, as well as evidence for internal divisions within the enclosure. The excavator interpreted this site as a high-status early historic settlement, possibly an estate centre of a hitherto unrecognised type (Barclay 2001). No buildings were identified within the enclosure, however, due to the modern damage to the site and limited excavation.

The form of the Dornoch Phase 2 building, either a small sub-rectangular structure with rounded corners, or the rounded end of a longer rectangular structure, does have some parallels other than on monastic sites. As a rectangular structure with rounded ends, it could represent an example of the 'Pitcarmick-type' building recognised further south in Perthshire (Barrett \& Downes 1997). As a smaller sub-rectangular structure, it can be paralleled by a series of timber structures excavated at Easter Kinnear, and dated to the 6th-8th centuries AD (Driscoll 1997). Here, there was evidence of up to five rebuilds on the same site, and all of these were found to have ditches around the circumference, but there was no trace of a central post to support the roof. It is presumed by the excavators that the roof was supported by the wall posts, and the gaps between the posts filled in with wattle and daub panels, bedded in the trenches.

The structural remains, the evidence for ironmaking and -working and the, albeit limited, artefactual assemblage recovered from The Meadows Business Park suggest that Dornoch was subject to influences from both Norse and Pictish contexts. Lying on the boundary as it does between the Norse and Pictish lands and in the context of the emerging Scottish nation, the Dornoch Firth area can be seen to occupy an important point of contact where all these influences met. Perhaps we need look no further than this strategic position for the reason behind the later establishment of the see at Dornoch, but it is possible that further discoveries relating to the extent and importance of pre-burghal settlement at Dornoch remain to be made. 


\section{Acknowledgements}

All specialist reports were edited for publication by Russel Coleman. The authors would like to thank local archaeologist Charlie Miller, Resurgam!, for his help during the excavation and writing-up of this paper. Thanks also to the Tain Archaeology Group and students from the Aberdeen Univer- sity, Certificate of Field Archaeology, for their help during the excavation. The fieldwork was funded by Highland Council; the writing up of the results and the publication of this paper were funded by Historic Scotland. Highland Council Archaeology Service provided a curatorial role during the fieldwork. 


\section{References}

Bangor-Jones, M 1995 'Norse settlement in south-east Sutherland' in B E Crawford (ed) Scandinavian Settlement in Northern Britain. Leicester.

Barclay G J 2001 'The excavation of an early medieval enclosure at Upper Gothens, Meiklour, Perthshire' in Tayside \& Fife Archaeological Journal, 7, 34-44.

Barrett J \& Downes J 1997 'Pitcarmick' in Discovery and Excavation in Scotland, Council for Scottish Archaeology, Edinburgh.

Barrow, G W S 1981 Kingship and Unity: Scotland 1000-1306. London.

Batey, C 1988 'A Viking bell from Freswick Links' in Medieval Archaeology 22, 213-16.

Batey, C 1993 'The Viking and Late Norse graves of Caithness and Sutherland' in C E Batey, J Jesch \& C D Morris (eds) The Viking Age in Caithness, Orkney and the North Atlantic. Edinburgh.

Bethune, J 1793. The Statistical Accounts of Scotland, Vol. 8.

Biddle, M \& Hinton, D A 1990 'Copper-alloy bells' in $\mathrm{M}$ Biddle Object and economy in Medieval Winchester: Artefacts from Medieval Winchester. Oxford.

Boyd, W E 1988 'Cereals in Scottish Antiquity' in Circaea 5 (2), 101-110.

Bronk Ramsey, C 1995 'Proc. 15th Internatl. 14C Conf', Radiocarbon 37 (2), 425-430.

Callander, J G 1924 'Fourteenth-century brooches and other ornaments in the National Museum of Antiquities of Scotland' in Proc Soc Antiq Scot 58 (1923-4), 160-84.

Carver, M 2004 'An Iona of the East: The Earlymedieval Monastery at Portmahomack, Tarbert Ness' in Medieval Archaeology 48, 1-30.

Cerón-Carrasco R 2000 'The Meadows Business Park, Dornoch: the fish remains'. Archive report. SUAT Ltd.

Chambers, F M \& Jones, M K 1984 'Antiquity of Rye in Britain' in Antiquity 58 (224), 219-223.

Chenery, S 2001 'Geochemical fingerprinting of Dornoch pottery'. Archive report. SUAT Ltd.

Coleman, R 1997 'An Archaeological watching brief at the Meadows Business Park Dornoch'. Archive report. SUAT Ltd.

Coleman R, 2000 'An Archaeological watching brief and an excavation at The Meadows Business Park, Dornoch'. Archive report. SUAT Ltd.

Cowan, I B and Easson, D E 1976 Medieval Religious Houses; Scotland. London.

Cox, A 1994 'The finds' in D P Bowler and R Cachart 'Tay Street, Perth: the excavation of an early harbour site' in Proc Soc Antiq Scot, 124 (1994), 481-4.
Cox, A forthcoming 'Copper alloy objects' in D R Perry et al 'Excavations in Ayr, 1984-7'.

Cox, A 2000 'The Meadows Business Park, Dornoch: the artefacts'. Archive report. SUAT Ltd.

Crawford, B E 1986 'The making of a frontier: the firthlands from the ninth to twelfth centuries' in J R Baldwin Firthlands of Ross and Sutherland. Edinburgh.

Crawford, B E 1987 Scandinavian Scotland. Leicester.

Crawford, B E 1995a Earl and Mormaer: NorsePictish relationships in Northern Scotland. Rosemarkie.

Crawford, B E 1995b 'Introduction: The study of place-names' in B E Crawford (ed) Scandinavian Settlement in Northern Britain. Leicester.

Driscoll, S T 1997 'A Pictish settlement in north-east Fife: the Scottish Field School of Archaeology excavations at Easter Kinnear' in Tayside \& Fife Archaeological Journal 3, 74-118.

Dunning, G C 1952 'Anglo-Saxon discoveries at Harston' in Trans Leicestershire Archaeol Hist Soc 28 (1952), 48-54.

Egan, G \& Pritchard, F 1991 Dress accessories. London.

Fraser, I 1986 'Norse and Celtic place-names around the Dornoch Firth' in J R Baldwin Firthlands of Ross and Sutherland. Edinburgh.

Goodall, I H 1980 'Objects of copper alloy' in P WadeMartins Excavations in North Elmham Park, 1967-72 (= East Anglian Archaeol Rep. No 9). Norwich.

Grant, I F 1995 Highland Folk Ways. Edinburgh.

Green, F 1981 'Iron Age, Roman and Saxon crops: the archaeological evidence from Wessex', in M. Jones and G. Dimbley (eds) The Environment of Man: the Iron Age to the Anglo-Saxon Period, BAR, British Series 87, 129-53.

Hall, A J, Atkinson, E J A, Banks, I and PhotosJones, E 1998 'The bloomery mounds of the Scottish Highlands. Part 1: the archaeological background' in Journal of the Historical Metallurgy Society, 32 (1), 13-32.

Hall, A J and Photos-Jones, E 1998 'The bloomery mounds of the Scottish Highlands. Part 2: a review of iron mineralisation' in Journal of the Historical Metallurgy Society, 32 (2), 54-66.

Hall, D W 1996 'Blind Date - Scottish medieval pottery industries' in Tayside \& Fife Archaeological Journal, Vol. 2, 126-128.

Hall, D W 1999 'Medieval pottery from the church excavation at Portmahomack' in Tarbat Discovery Programme Bulletin No. 4 (1998), 17-19.

Hall, D W 2000 'The Meadows Business Park, 
Dornoch: the pottery'. Archive report. SUAT Ltd.

Hastie, M 2000 'The Meadows Business Park, Dornoch: the plant remains'. Archive report. SUAT Ltd.

Hastie, M 2000 'The Meadows Business Park, Dornoch: wood charcoal identifications'. Archive report. SUAT Ltd.

MacGregor, A 1985 Bone, antler, ivory and horn: the technology of skeletal materials since the Roman period. London.

McGreggor, M, Lee, G W and Wilson, G V 1920 The ores of Scotland, Special Reports on the Mineral Resources of Great Britain. Tansfiels.

McNeill, P G B and MacQueen, H L 1996 Atlas of Scottish History to 1700. Edinburgh.

Nicolaisen, W F H 1986 Scottish Place-Names. London.

Photos-Jones E and Atkinson, J A 1998, 'Iron working in Medieval Perth: a Case of Town and Country?' in Proc Soc Antiq Scot, 128 (1998), 887-904.

Photos-Jones, E 1999a, 'The scientific characterisation of the Dornoch metallurgical waste; also the technical characterisation of a select number of other materials (pottery, glaze, shells and bone)', SASAA Internal Report 34.2.

Photos-Jones, E 1999b, 'The metallurgical characterisation of the Tarras farm, by Forres. Bloomery iron industrial waste: Scotland's earliest dated bloomery furnace?' SASAA Internal Report 40.

Photos-Jones, E 2000 'The Meadows Business Park, Dornoch: Metallurgical Waste Analysis'. Archive report.

Photos-Jones, E 2004 'A site like KAY, the technical examination of metallurgical waste from Killickaweeny, Co. Westmeath', SASAA, 112.

Ritchie, A 1993 Viking Scotland. London.

Samson, R 1982 'Finds from Urquhart Castle in the National Museum, Edinburgh' in Proc Soc Antiq Scot 112, 465-76.

Scott, A B 1915 'Chapters in the history of the church of the Picts (ii) - S. Finbarr of Caithness and Ulster' in Trans Gaelic Soc Inverness, 27 (1908-11), 24.

Simpson, A and Stevenson, S 1982 Historic Dornoch: The Archaeological Implications of Development (= Scottish Burgh Survey Series) Dept of Archaeology, University of Glasgow.

Smith, C 2000 'The Meadows Business Park, Dornoch: the faunal remains'. Archive report. SUAT Ltd.

Stones, J A (ed) 1989 'Three Scottish Carmelite friaries: Excavations at Aberdeen, Linlithgow and Perth 1980-86' in Soc Antiq Scot Monogr Ser 6, Edinburgh.

Stuiver et al 1998 'Intcal98 Radiocarbon Age Calibration, 24,000-0 Cal Bp' in Radiocarbon 40 (3), 1041-1083.

Tarbat Discovery Programme 1998 Bulletin No. 4. University of York.

Tarbat Discovery Programme 1999 Bulletin No. 5. University of York.

Watson, J A S and More, J A 1962. Agriculture: The Science and Practice of Farming. Edinburgh.

Watson, W J 1926 The History of the Celtic Placenames of Scotland. Reprinted 1993, Birlinn Ltd, Edinburgh.

Will, R 1999 'Tarras by Forres', Glasgow University Archaeological Research Division Internal Report 567. 